\title{
Modern Industrial Robotics
}

\author{
Mariusz Olszewski \\ Warsaw University of Technology, Faculty of Mechatronics, Institute of Automatic Control and Robotics, ul. św. Andrzeja Boboli 8, 02-525 Warszawa
}

\begin{abstract}
In the past decade, robots have become the basic tools for the automatization and robotization of industrial production, as they used to be in the 70 s programmable controllers, in the 80 s processor drive controllers, in the 90 s of the twentieth century frequency controlled AC motors and in the first years of the 21 st century digitization, expressed in the significant advancement and dissemination of computerization, telecommunications and internetization. This role is evidenced by further, beyond conventional robotics, extension of its application and the emergence of new hardware and software solutions oriented towards joint, by robots and human, undertaking of hitherto not rationalized production tasks. This essay is devoted to these transformations in contemporary robotics.
\end{abstract}

Keywords: robotics, constructions, kinematics, control, programming, industrial application, Industry 4.0

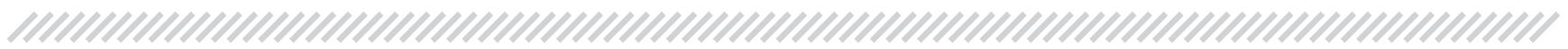

\section{Introduction}

The International Federation of Robotics (IFR) reported that globally, in 2018, the value of sales of robots increased to USD 16.5 billion, which corresponds to the use of 422,000 robots and an annual increase of $6 \%$. In just 5 years, from 2013 , the number of machines installed annually increased by as much as $135 \%$. These values, despite the currently visible economic recession, are also to remain in 2019 and then increase until 2022 even at double-digit rate. At the same time, it should be noted that in 2018 as much as $74 \%$ of new robot appli-

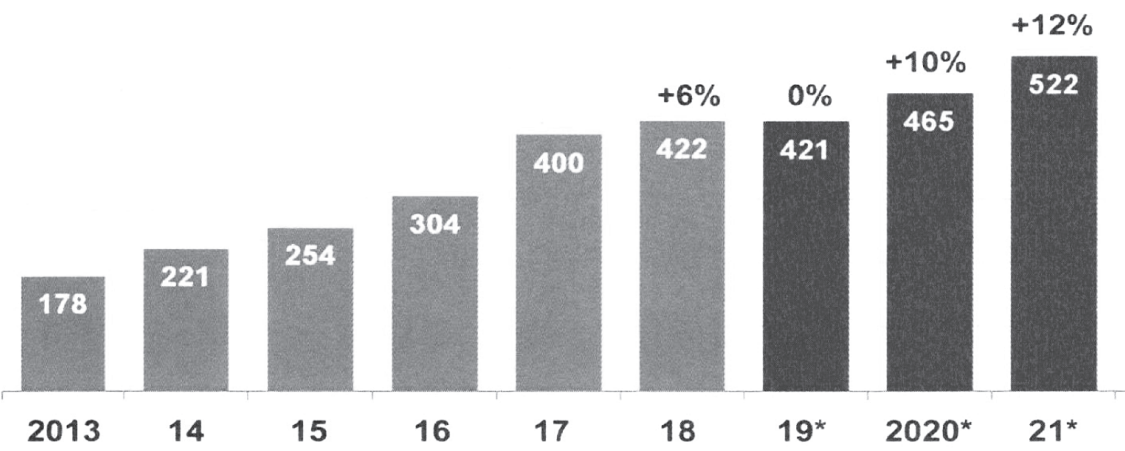

Fig. 1. Global deliveries of industrial robots (in thousands of machines, *) forecast) - IFR, 2019 Rys. 1. Sprzedaż robotów przemysłowych w skali świata (w tysiącach maszyn, *) prognoza) - IFR, 2019 $[33,46]$ cations were made in the industries of only five countries: China, Japan, South Korea, the USA and Germany. In this group, however, China's industry is by far the largest recipient of robots - in 2018, 154,000 were installed in it new machines, it is also the largest user in the world - it has completed as much as $36 \%$ of all global robotization installations in production processes. All this confirms the aforementioned thesis about the global importance of robotics and its place as currently the main tool for rationalizing production processes on a global scale [33, 46, 54].

In the last few year the density of robotization has been adopted as a modern indicator of just technical rationalization

Autor korespondujący:

Mariusz Olszewski, marindustry4.0@gmail.com

Artykuł recenzowany

nadesłany 24.10.2019 r., przyjęty do druku 11.02.2020 r.

of production processes carried in enterprises and industries imposing the same product area, or even in regions and countries, expressed in the number of installed machines per 10,000 employees. In this competition, from the five leading countries in robotics investments, Singapore comes first with 831 machines per 10,000 employees, ahead of South Korea, Germany and Japan - the United States came in $8^{\text {th }}$ place, and China only in $20^{\text {th }}$ place. Relationship of this index with demographics and population size obvious here [46]. Polish economy with 36 robots per 10,000 employees are unfortunately out of this competition - although companies' problems related to the lack of hands to work in a similar demographic situation as Poland is today and thanks to intensive robotics investments came to the fore of economically leading countries on a regional scale and then, in terms of product quality, on a global scale [20].

Apart from the product and state of robotization division and focusing on the modern state of industrial robotics, six subclasses of robot class manipulation machines can be distinguished [19]:

- conventional robots that perform standard programming, control and use tasks in countless industrial applications since the late 1960s. It is worth recalling here that in 1968, 


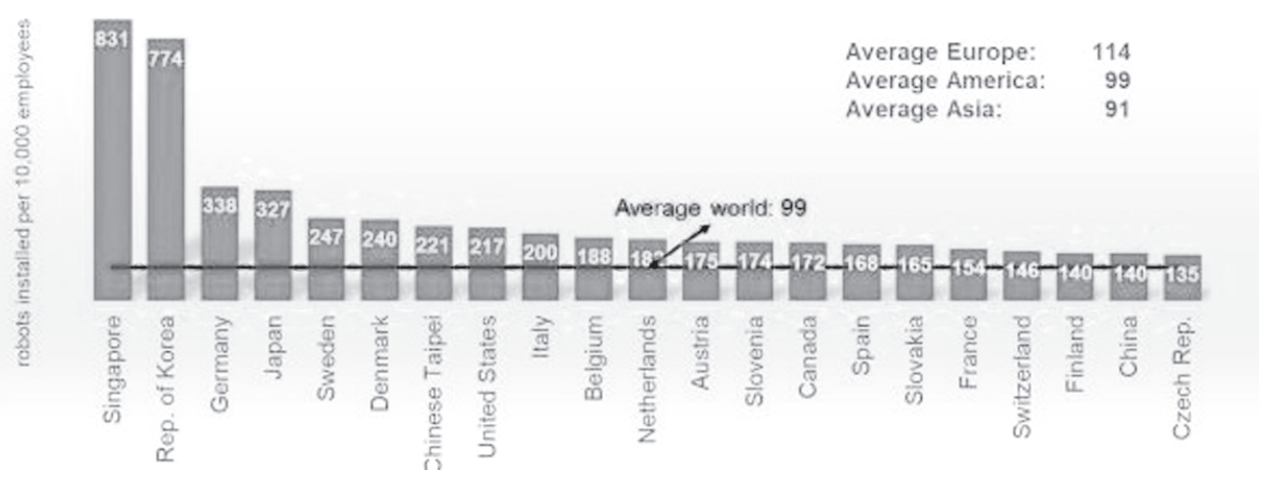

Fig. 2. Density of robot applications in industrial production worldwide (the number of machines per 10,000 employees) - IFR - World Robotics, 2019

Rys. 2. Intensywność robotyzacji produkcji przemysłowej w skali świata (liczba maszyn na 10.000 pracowników) - IFR - World Robotics, 2019 [46]

the pioneering company for the development of robotics, Unimation managed to use as much as 48 robots for the first time across the world, but by assigning this date a breakthrough, symbolic beginning of the robotization era,

- cooperating robots, cobots, performing tasks referred to as MRK (Men-Robots-Collaboration),

- hybrid robots, for both conventional and collaborative robotics tasks,

- service robots, including cobots,

- multi-chain robots, with a twinarms or parallel kinematic structure, including cobots,

- mobile robots performing locomotion and manipulation tasks in the area of production and intralogistics of the Industry 4.0 character.

\section{Conventional Robotics}

Conventional industrial robots nowadays the most commonly used subclass of robots, which ensures robotization of machines, workstations and production processes in industries only reminding in turn about their application importance: automotive and working machines, mechatronic and electromechanical, including household appliances, information and telecommunications techniques, machine tools and tools, metallurgy, plastics and rubber processing, also packaging, beverage and food, pharmaceutical, cosmetics and medical products, wood processing, chemical, paper and printing, construction, also construction of renewable energy equipment and machinery $[1,6,12,16,22,26]$.

A characteristic structural solution of the mechanisms of modern industrial robots is a series structure (also called a chain) of kinematic members, performing mutually rotational movements, divided into two groups: three regional members with the structure $\left\{\mathrm{C}_{\mathrm{R}}, \mathrm{B}_{\mathrm{R} 1}, \mathrm{~B}_{\mathrm{R} 2}\right\}$, ensuring that the effector reaches the set position in the manipulative space machine and one, two or three local members ensuring orientation of the machine effector. This provides a total of four, five or six degrees of mobility of the mechanism and an appropriate number of degrees of freedom of the effector, so in the case of a mechanism with six members virtually any free arrangement of the effector in the working space of the machine mechanism. Restrictions on the number of mechanisms' mobility are a consequence of the machine's application areas proposed by the manufacturer and the desire to reduce its cost.

In principle, only two kinematic solutions of the local group are used - in the case of three members they are structures: $\left\{A_{L 1}, B_{L}, A_{L 2}\right\}$ and $\left\{C_{L}, B_{L}, A_{L}\right\}$, in the situation of limited

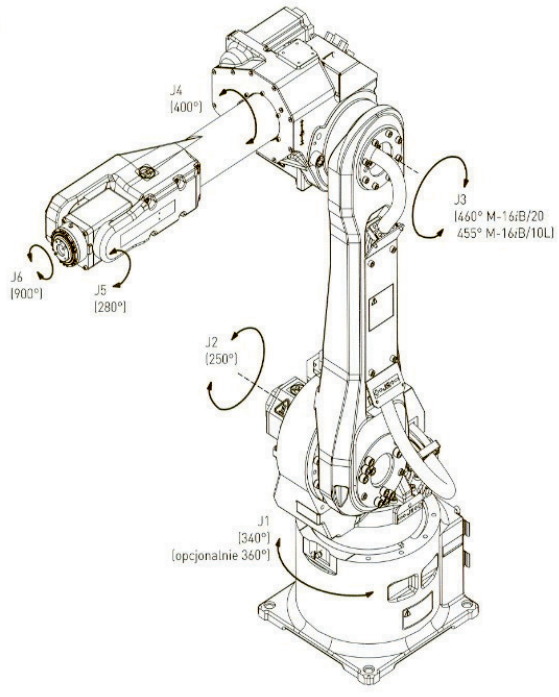

a)

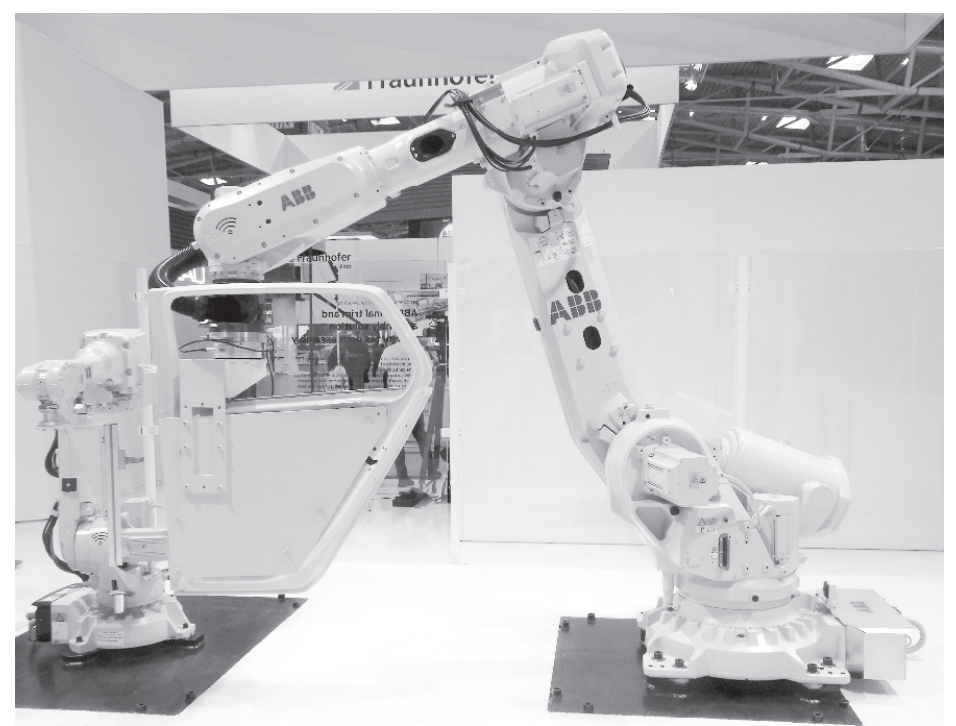

b)

Fig. 3. A typical mechanism of a modern industrial robot with six levels of mobility and kinematic structure $\left\{C_{R}, B_{R 1}, B_{R 2}, A_{L 1}, B_{L}, A_{L 2}\right\}:$ a) sketch of construction, b) ABB Automation $\mathrm{GmbH}$ robot mechanism on a stand demonstrating cooperation with the turntable mechanism, increasing the degree mobility of a set of two handling machines

Rys. 3. Typowy mechanizm współczesnego robota przemysłowego o sześciu stopniach ruchliwości i strukturze kinematycznej $\left\{C_{R}, B_{R 1}, B_{R 2}, A_{L 1}, B_{1}, A_{t 2}\right\}$ : a) szkic budowy; b) mechanizm robota firmy ABB Automatic $\mathrm{GmbH}$ na stanowisku demonstrującym współpracę z mechanizmem obrotnicy powiększającym liczbę ruchliwości zestawu dwóch maszyn manipulacyjnych [12, 35] 
Fig. 5. M-2000A / 2300L robot with a load capacity of $2300 \mathrm{~kg}$ and an unladen weight of $11,000 \mathrm{~kg}$ of Fanuc Deutschland $\mathrm{GmbH}$, based on global linear motion guides (7. mobility level) of the Swiss company Güdel Group AG Rys. 5. Robot M-2000A/2300L o obciążalności 2300 kg i masie własnej 11 tys. kg firmy Fanuc Deutschland $\mathrm{GmbH}$, osadzony na prowadnicach globalnego ruchu liniowego (7. stopień ruchliwości) szwajcarskiej firmy Güdel Group AG $[42,45]$

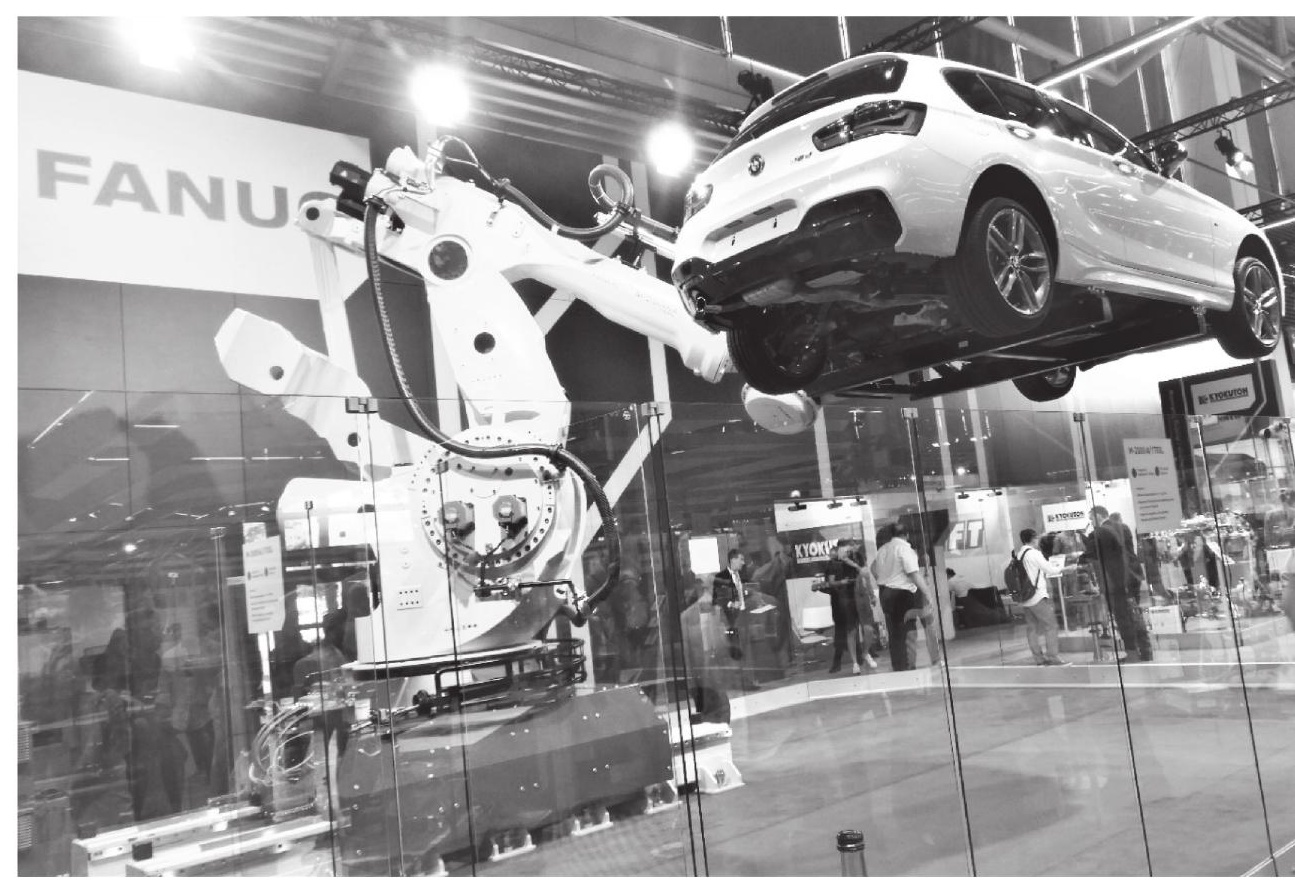

mobility of the mechanism, the last element before the effector is the $A_{L}$ member rule, ensuring rotation of the effector on the structural axis of this member and most often on the structural axis also of the third, last before the local group, regional member, i.e. $\mathrm{B}_{\mathrm{R} 2}$. This makes it easier for the machine operator to program the effector's trajectory, more precisely the current location of the tool's central point, i.e. TCP (Tool Center Point) and the effector's approach vector to the object of manipulation or machining.

Since the end of the 1990s, the use of AC electric servo motors has been popularizing in the construction of industrial robot mechanisms - thanks to the introduction of new neodymium magnetic materials - hence the absolute advantage of rotational motion and given kinematic structures. Electric but

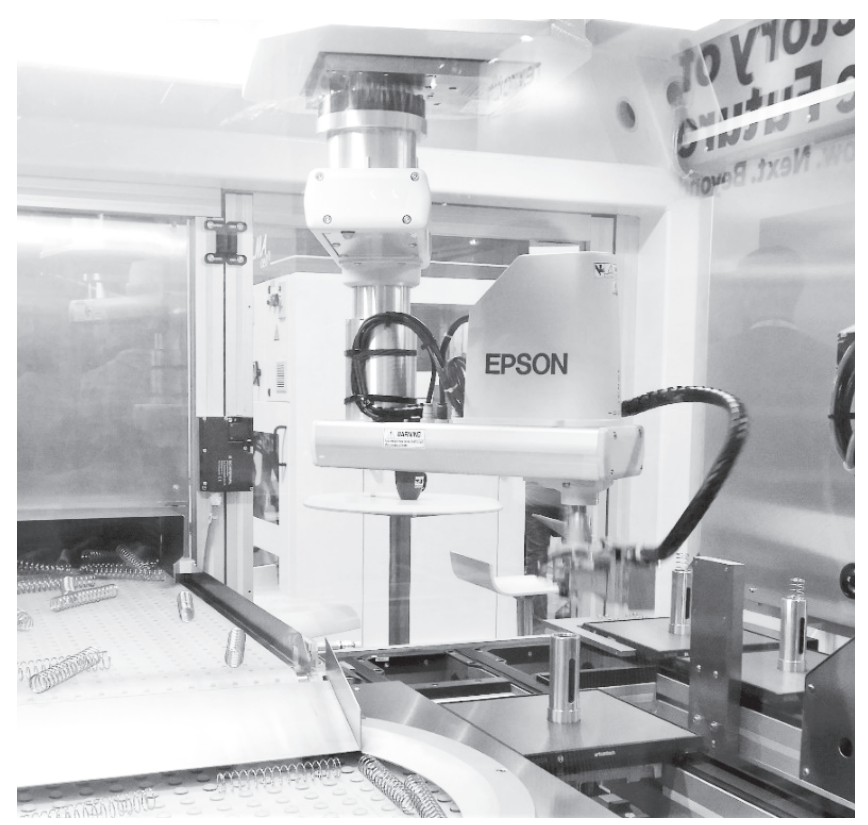

Fig. 4. Modern version of the SCARA robot mechanism, manufactured by Epson Europe B.V., used in the process of checking the implementation and selection of spring

Rys, 4. Współczesna wersja mechanizmu robota SCARA, produkcji firmy Epson Europe B.V., zastosowanego w procesie kontroli wykonania i selekcji sprężyn $[12,41]$ direct-current (DC) servo drives were used in robotics for the first time in 1974 by the Swedish company ASEA, earlier exclusively and still later, above $60 \mathrm{~kg}$ load capacity, electrohydraulic servo and motor servo drives were used. Their advantage was very high, especially hydraulic motors, energy efficiency in relation to the mass and volume of the engine, hence it was possible to attach to each component of the mechanism its own drive. Despite the indisputable utility and energy advantages of AC servo motors, their lower energy efficiency and corresponding higher mass and volume are forcing manufacturers to a different way of driving local members. They are placed on the last regional member $\left(\mathrm{B}_{\mathrm{R} 2}\right)$ in front of the local group, and the transfer of movement through the length of this member and other local members, e.g. to the $A_{L}$ member, must be provided by shaft and toothed belt gears [26, 34].

We should also mention the drive of the first member $\left(\mathrm{C}_{\mathrm{R}}\right)$ of the described kinematic structure - in classic solutions it was a drive located in the foundation of the machine mechanism, and thus requiring the hollow of the ground or raising the mechanism above the needs of its actions, which sometimes caused problems with placing the mechanism e.g. on walls or posts of the production hall. Therefore, some modern manufacturers suggest reversing this design: the drive is mounted on this element, which facilitates applications, but by increasing the load on the element, it forces the machine to use more energy.

Linear motion drives have practically ceased to be used in the construction of conventional industrial robot mechanisms a certain exception is the use of various types of global motion drives along the lines of supported production machines. The only regional mechanism, but used only for the tasks of operating machine tools as well as injection and foundry machines, is the SCARA (Selective Compliance Assembly Robot Arm or Selective Compliance Articulated Robot Arm) robot mechanism known since 1981 [18], with three or less often four degrees of mobility and structures $\left\{\mathrm{C}_{\mathrm{R} 1}, \mathrm{C}_{\mathrm{R} 2}, \mathrm{Z}_{\mathrm{L}}\right\}$ or $\left\{\mathrm{C}_{\mathrm{R} 1}\right.$, $\left.\mathrm{C}_{\mathrm{R} 2}, \mathrm{Z}_{\mathrm{R}}, \mathrm{A}_{\mathrm{L}}\right\}$ or also $\left\{\mathrm{Z}_{\mathrm{R}}, \mathrm{C}_{\mathrm{R} 1}, \mathrm{C}_{\mathrm{R} 2}, \mathrm{~A}_{\mathrm{L}}\right\}$ - here a single, local or regional linear movement along the $\mathrm{Z}$ axis is needed providing such just the effect of the effector serving these production machines.

A clear trend of recent years is the extension of the load capacity and geometric extent of industrial robot mechanisms. While in classic solutions of the previous decades, 


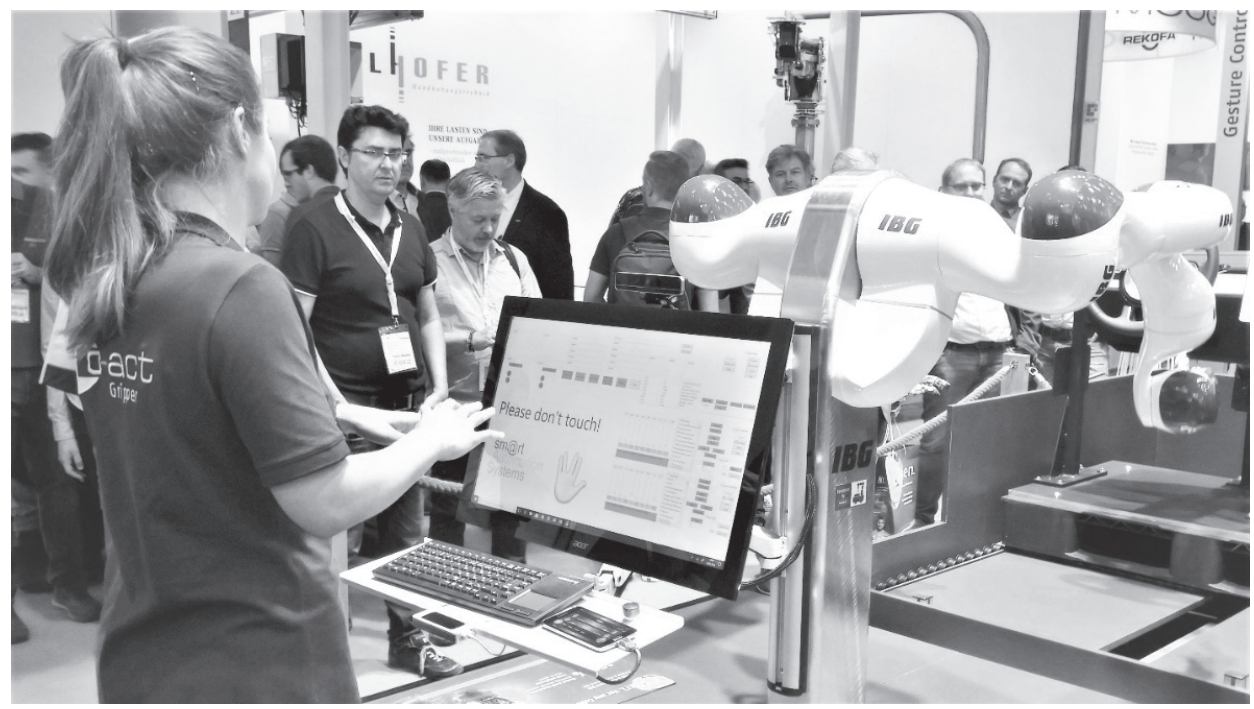

Fig. 6. Non-contact, but graphically supported and based on the operator's hand movements, programming and control of the mechanism of a robot with a parallel, open structure, IBG Automation $\mathrm{GmbH}$, equipped with a gripper Co-act, holding Schunk GmbH \& Co. KG

Rys. 6. Bezdotykowe, ale wspomagane graficznie i oparte na ruchach dłoni operatorki, programowanie i sterowanie mechanizmu robota o strukturze równoległej, otwartej, firmy IBG Automation $\mathrm{GmbH}$, wyposażonego w chwytak linii Co-act holdingu Schunk $\mathrm{GmbH} \&$ Co. KG $[19,50]$

the permissible mass loads were - on average - in the area from $6 \mathrm{~kg}$ to $60 \mathrm{~kg}$, now the upper load capacity is already $100 \mathrm{~kg}$, and the largest load capacity, $2300 \mathrm{~kg}$, has the Fanuc-M-2000A/2300L robot Deutschland GmbH weighing 11 tons, 6 degrees of mobility, repeatability of the TCP point position $\pm 0.18 \mathrm{~mm}$ and a range of movement over $3.7 \mathrm{~m}$. Even greater range, over $4.6 \mathrm{~m}$, with a slightly lower load capacity, $1700 \mathrm{~kg}$, has its neighbor in the Fanuc heavy machinery family: the M-2000A/1700L robot [42].

Contrary to popular belief, this tendency favors the needs of a number of industries relevant to the economy. Examples of application fields are the automotive industry, including service and repair of cars without the need for hydraulic ducts and lifts, metallurgy (foundries) and machinery (rail, ship, air transport, machining machinery, service and coupling of the stamping press and forge) without the need for time-consuming use of gantries, tire industry, mining industry (quarries), etc.

At the other end of the scale of permissible loads are miniature robots with very low load capacity - it is assumed for this class of machines as a limitation of $1 \mathrm{~kg}$ capacity. An example of such a compact machine with a miniature mechanism is the MotoMINI robot from YASKAWA Europe GmbH [56] with a load capacity of $500 \mathrm{~g}, 6$ degrees of mobility, repeatability of the TCP position $\pm 0.03 \mathrm{~mm}$ and a range of motion not exceeding $350 \mathrm{~mm}$. The robot is equipped with the Motoman YRC1000micro controller, developed especially for such small machines. Just a few kilograms weight and the compact dimensions of MotoMINI make it easy to set up the robot in different, changing places in the production line.

Conventional industrial robots are programmed by teaching the desired machine effector motions by the machine operator - two modes, used yet in the 1960s, are used [16, 18]:

- point programming (multi-point teach-in programming, MP), also called simple programming. An indispensable device for teaching a simple manipulation machine is a controller or a programming or teaching panel (teach panel), which serves the machine operator to induce the desired movement of individual members by manually controlled servo drives of the mechanism and as a result of this change of shape and location of the TCP point effector and then, in the memory of the robot controller, the machine coordinate values determining the mutual relations of the mechanism members measured by rotary position transducers, e.g. encoders,

- follow-up programming (play-back programming or on-line programming), also called programming by predicting the planned motion trajectory. This concept, given in 1968, was derived from the observation of two facts: manual performance of certain technological activities by an experienced employee who can successfully meet the technological requirements of the robotized process and the possibility of using this experience to program the movement of the robot mechanism by manual effector/embedded tool on the mechanism, by the same employee, directly by hand or using a 3D joystick or control stick, allowing for remote forcing the spatial movement of a TCP point and also a corresponding change in the shape of the robot mechanism along with the current storage of current values of mutual positions (machine coordinates) of the mechanism members,

- and the third mode - given at the end of the 1980s and gradually spreading since the turn of the century, during a period of rapid digitization and computerization, i.e.

- computer-aided programming (off-line programming) implemented as:

- graphic programming (called virtual reality-programming or VR-Programming), based on a computer simulation image of a production station with embedded robot mechanism and a variant application of one of the above-mentioned programming methods,

- reverse or computer programming (computer aided design-programming or CAD-programming), using the well-known CAD documentation for the produced object of the robot tool trajectory path or its manipulation and computer path calculating the values of machine coordinates on this basis using the extent and geometric shape of the mechanism members and equations describing the dependence of machine coordinates on the location of the TCP point in the common base system of the real and virtually existing in the CAD space of the robot mechanism. It is a reversal of simple programming - in it manually setting machine coordinate values of the real or virtual machine mechanism in the manner described - calculation by the computer program of these values, and thus a reversal of simple programming, hence the good name in Polish.

Manufacturers of modern industrial robots have adopted, as a dominant principle, to provide the user with the use of two programming modes: the basic is computer-aided programming, currently most often in reverse and complementary - as simple programming. It mainly serves the robot operator during the start-up phase of the robotic station or production machine, allowing for correction and supplementing of missing effector transitions in computer implementation [1, 27, 28, 40, 54]. 
Fig. 7. Cooperation between the cobot from Fanuc Deutschland GmbH company and employees at the control and demonstration assembly stand

Rys. 7. Współpraca kobota firmy Fanuc Fanuc Deutschland GmbH i pracownicy na demonstracyjnym stanowisku kontrolnym i montażowym [42]

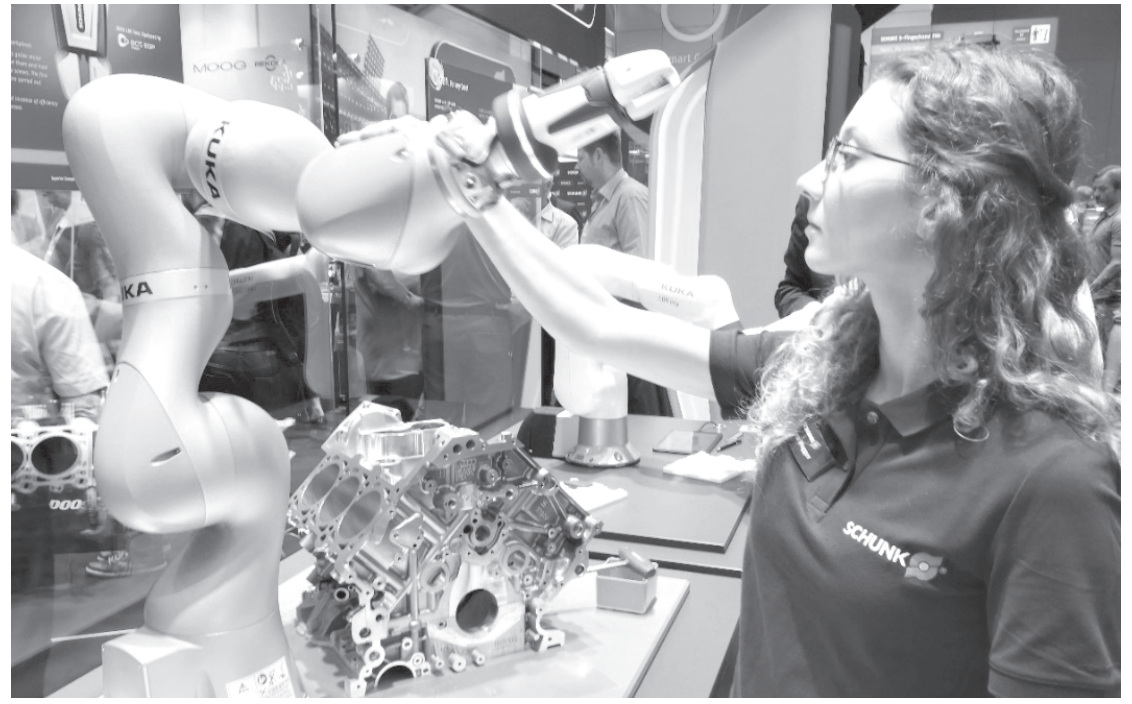

\section{Cooperating Robotics}

Cobots - cooperative or collaborative robots (hence the word cluster), are constructed for direct cooperation with the human-operator and human-worker (hence the very good Polish name: ,roboty wspótpracujace” $\rightarrow$ cooperating robots), supporting robotic stations, devices, machines and production lines $[23,31]$.

The first machines of this subclass of robots were created in 1996 at the University of Northwestern in Illnois for Intelligent Assist Devices for moving heavy loads in spaces requiring human presence and directing their movement. The essence of the application of cobots is the removal from the production space of both devices protecting against accidents caused by human collisions with conventional handling machines, as well as the removal of closed areas, intended only for the use of these machines, completely separated from the presence of man.

The increase in interest in cobots, seen in the last few years, is due to two reasons. The first is the conventional robotization of industry that accelerates equally dynamically, in these years, and the investors' willingness to reduce costs resulting from unused space for production purposes and from the introduction of additional safety devices unnecessary in production. The second, even more important, proved to be proven in industrial practice necessary presence of employees in most robotized production processes and not only for the maintenance (operational and service) of the handling machines themselves, but primarily for technological reasons. Nowadays, there is already the hypothetical possibility of robotizing any, even low-series production process, but the cost of such investment and the time of its amortization are incomparably large, simply unacceptable nowadays, in relation to the implementation of the same process involving manual work. This may apply only to some of the executive positions, but also in this case the presence of cobots or conventional robots and with cobotic behavior throughout the entire production process is desirable, for reasons of work safety of people employed therein even at other conventionally robotic positions.

The above-mentioned verbal interest in cobots does not yet translate into equally clear use of these machines in practice. In 2018, according to IFR, among 422,000 global machines installed, cobots are only 11,000 machines, i.e. in percentage terms $3.2 \%$ of all installed handling machines [46, 54]. Nevertheless, a clear increase in the number of these machines is expected in the near future, not only in industry, but in areas such as surgery and the service of people with this kind of care [24].
The essence of the construction of cobots is to bring the structure, drives, sensors and control of the machine mechanism closer to the limited movement possibilities of the arm/ arms of the man and his specifically bionic sensoric and current capabilities, both kinematic and kinetic. Unlike conventional robots, usually made of extruded or metallurgical profiles, with measuring elements and drive assemblies mounted outside, the elements of the cobot mechanism are made of shell, plastic or metallic fittings hiding all necessary elements and load-bearing assemblies (if there is a need to stiffen the outer shells) and executive motion, from sensors, through motors, gears, connection axis construction to power, signal and network cables. In this new, anthropomorphic or bionic way, the desired geometry, structure and rigidity of the cobot's kinematic chain are provided. At the same time, the smooth, round, often soft (through the outer material or plastic lining) chain of the machine mechanism meets most of the desirable human requirements for contact of his body and arms with a "foreign" object. Hence the almost indistinguishable similarities in the appearance of cobots in the catalogs of manufacturing companies.

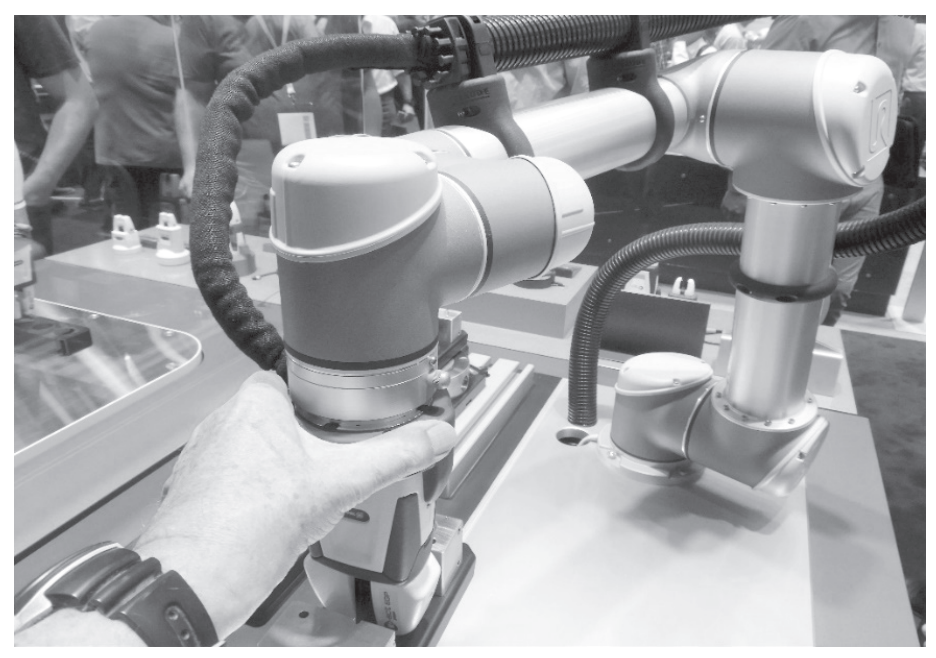

Fig. 8. Programming the trajectory of the cobot effector motion by teaching, consisting in forcing the movement (as the author does with your hand) of one of the mechanism members and through this movement changing the shape of the mechanism and the location of the TCP point

Rys. 8. Programowanie trajektorii ruchu efektora kobota przez nauczanie, polegające na wymuszeniu ruchu (jak czyni to autor dłonią) jednego z członów mechanizmu i przez ten ruch zmiany kształtu mechanizmu i położenia punktu TCP [19] 
In the area of motion and control parameters, cobots differ significantly from conventional robots - the main differences relate to the fulfillment of the mentioned requirements for safe, ergonomically consistent cooperation with humans - of course, and to the values of motion parameters, mechanism weight, its lifting capacity and positioning repeatability, also for machine prices. Averaging - this is expressed in the reception:

- limited linear motion speed of mechanism and effector members, maximum values in non-collaborative mode do not exceed $1 \mathrm{~m} / \mathrm{s}$, in collaborative mode they are several times lower and depend on the speed of movement of the operator's arm and hand,

- equally limited speed of the effector rotation, maximum values in non-collaborative mode do not exceed $135-400^{\circ} / \mathrm{s}$, in collaborative mode they depend - as above - only on the operator,

- very small, compared to conventional machines, unit masses and load capacity (kinematic chain load capacity) machines, taking into account ergonomically acceptable loads for a person, which depend on the applications adopted and the type of work expended by a man - these are values or definitely less than $10 \mathrm{~kg}$ (e.g. $4 \mathrm{~kg}$ capacity), or with a slightly increased range of 10-20 kg (e.g. $14 \mathrm{~kg}$ ),

- allowing displacement by the operator of the entire, nonfunded mechanism in relation not only to a given position, but also to several positions of the production line - hence the mass of the mechanism must take into account the ergonomics of the load imposed on the movement of people moving or moving this mechanism - this mass usually does not exceed $30 \mathrm{~kg}$,

- the effective range of the effector's movement to the ergonomically recommended spaces for human movement, sitting or standing at the stand, i.e. from $400 \mathrm{~mm}$ to $800 \mathrm{~mm}$,

- repeatability of positioning of movements programmed by the movement of a human hand - this value can be even within $\pm 0.15 \mathrm{~mm}$, however, it is usually higher, even by an order of magnitude,

- programming the effector trajectory by teaching, consisting in manually guiding and setting selected members or the effector and thus changing the shape of the mechanism and the position of the TCP point with it - this is the most cobotic way of programming these machines,

- prices of cobots, currently higher than conventional machines with similar performance parameters, from 40,000 USD up to 70,000 USD - weighs here extensive sensor and specifically "soft" mechanism construction. It is assumed that when considering using the offer of cobots on the Polish market, you need to prepare for an expenditure of 100,000 PLN.

Requirements for safe human cooperation with the Men-Robots-Collaboration machine are specified in the ISO/TS 15066 standard (Robots and Robotic Devices - Collaborative Robots) - these are four permitted situations of mutual contact, i.e. cooperation or collaboration [12, 34, 40, 54]:

- situation 1: some detention; the cobot (or hybrid robot) mechanism stops when a person enters (even slipping a hand) into the machine's working space,

- situation 2: handling with the hand; after activating the safe operation switch (otherwise the mechanism is stopped), it is possible to operate the mechanism with a human hand after determining the appropriate force (moment) measured with the sensor, affecting the mechanism,

- situation 3: speed and distance control, the machine's working space is divided into several zones, detected overrun (e.g. by a laser scanner), the first, outer zone reduces the speed of movement, exceeding subsequent zones - further reduction of its value, exceeding the proper working space of the machine - complete stop of the movement of the mechanism,

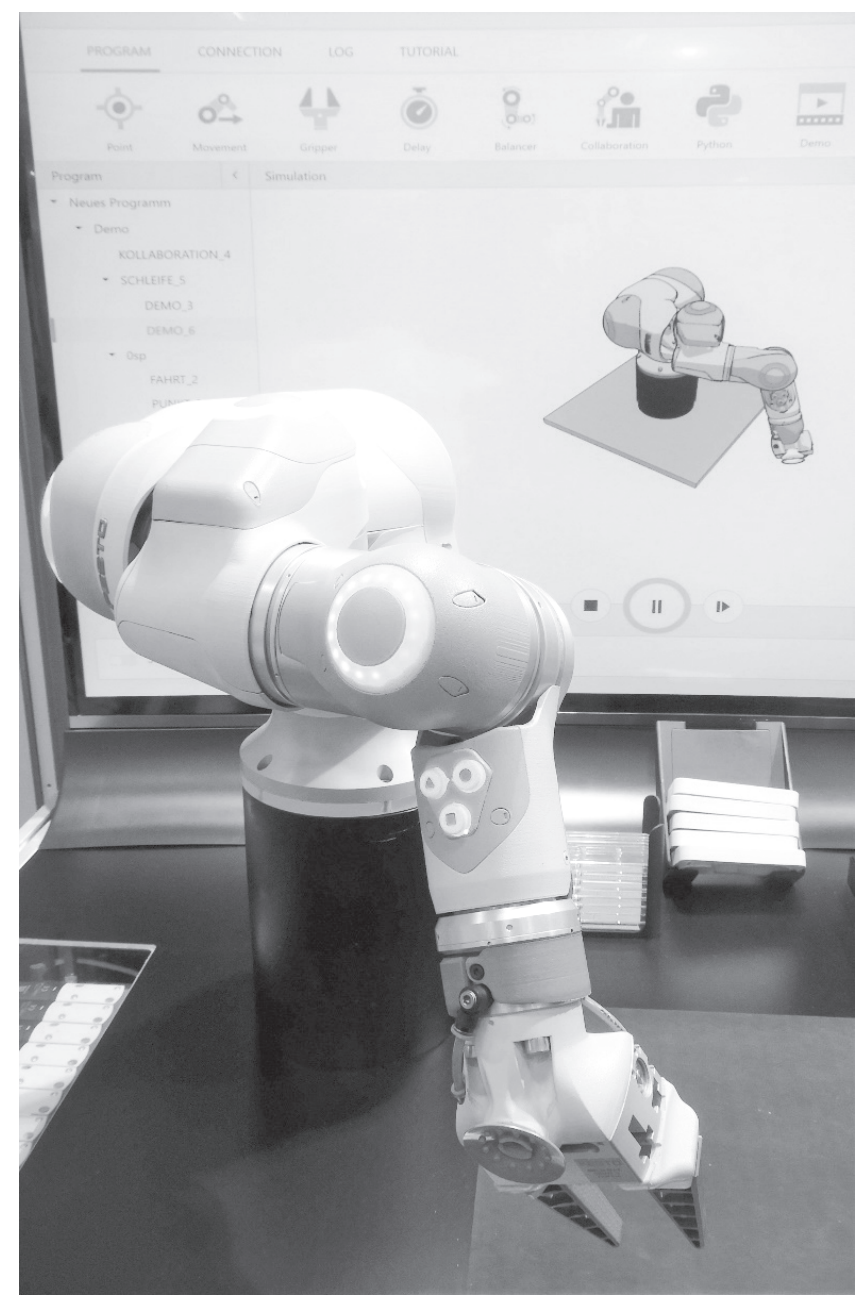

Fig. 9. BionicCobot of Festo AG \& KG holding with pneumotronic vane servo motors: three control buttons (programming, stopping, starting the program) and a virtual display of the behavior and programming of the cobot mechanism are visible

Rys. 9. BionicCobot holdingu Festo AG \& KG z pneumotronicznymi serwosilnikami łopatkowymi: widoczne trzy przyciski sterowania (programowania, zatrzymania, startu programu) oraz ekran wirtualnej prezentacji zachowań i programowania mechanizmu kobota [19, 43]

- situation 4: reduction of strength and energy expenditure; given in the Technical Specification (TS) description of this situation: the maximum values of forces (moments) or energy expended by the mechanism, after their initiation, are impassable values.

A particularly interesting solution belonging to this group of robots is BionicCobot (Festo Vertrieb GmbH \& Co. KG) $[29,30,43]$. A solution already known in 2017, but still awe-inspiring with a huge number of problems that have been successfully solved. The robot mechanism and its geometrical expanses perfectly meet the ergonomic requirements of the human figure, including its speed, acceleration and load parameters. It is possible to program its movements with all three of the aforementioned methods used in conventional, onand off-line robotics, it is especially convenient to program by teaching that meets the requirements of collaboration by operating the mechanism by hand (Method 2). This was achieved by the consistent application of a pneumotronic servo drive using vane rotary actuators. Thanks to this, the mechanism is "soft", it is carried out smoothly by hand, position and trajectory setting is very easy, when parked, it does not consume energy, the forces implemented correspond to those known from drive pneumatics (supply pressure 6 bar). However, this is definitely the most difficult, referring to the solutions of robots with electric drives, type of positioning drive (in the margins 
of the pneumotronics problem: it was solved for the Festo company at the Institute of Automatic Control and Robotics of the Warsaw University of Technology in the turn of the $20^{\text {th }}$ and $21^{\text {st }}$ centuries $\left.[13]\right)$.

The perfect complement to the mechanisms of cobots is proposed by the holding Schunk GmbH \& Co. KG, Co-act effectors family. It consists of four gripper effectors, the most advanced Co-act JL1 has [50]:

- capacitive proximity sensors for collision situations,

- cown touch screen enabling communication of the effector with the employee-partner of the cobot, teaching the effector involves showing the effector the object being captured and switching the effector modes of operation,

- a video camera placed between the fingers of the gripper to identify the object being captured,

- two types of gripping: scissor and vise (parallel),

- the ability to set the desired gripping force,

- tactile sensors distinguishing between the object being captured and the human-partner's hand,

- optical notification of the "human" partner about the effector's work status and identification of the object being captured.

The basic ways of programming cobots are basically identical to the programming modes of conventional robots. As a good example, you can take the rules adopted by the undoubted leader in the market of cobotics, the Danish company Universal Robots A/S. Namely, the company has set the mechanisms ease of use and programming of their movements. The software uses the Linux system, simplifying programming and, above all, reducing the training time of operators and employees, which works great in the case of point motion path design programs, worse in the case of cooperation with external devices and systems, based on data exchange. Understanding these difficulties, the company established close cooperation with manufacturers of external devices, i.e. effectors, sensors and actuators, as well as cooperation with software producers. Therefore, the UR+ platform has been built into the company's system, allowing the integration of its own UR system with third-party devices and software.
As the tab-windows of the UR cobot program were adopted [52]:

- startup screen, split into two windows: the program allows you to select various functions and modes of programming and dialog programming commands the position of the TCP trajectory,

- Move tab used to change the shape of the mechanism and change the resulting location of its TCP point - three modes are implemented here:

- Move Tool - used to perform the basic task of the bookmark, i.e. setting the TCP in the machine workspace by moving selected members,

- Move Joints - used to cause the movement of only one member of the mechanism, taking into account its limitations of geometric extent,

- Freedrive - used for cobotic programming of the shape of the mechanism using the hand/hand of the operator or employee. This programming method is permitted for robots with a load capacity of $3 \mathrm{~kg}$ and $5 \mathrm{~kg}$, for a robot with a load capacity of $10 \mathrm{~kg}$ (UR10), this movement should be allowed by pressing the motion enable button on the back of the programming panel (analogous to conventional robot programming panels),

- Graphics tab - visualizing the programmed trajectory of the mechanism's movement,

- Structure tab - allowing you to modify the designed program and add other functionalities to it by copying, cutting, pasting and disabling currently unnecessary parts of the program,

- Installation tab - implementing program settings, including input/output interfaces, security, and network protocols Profinet,

- The tab I/O - preview of inputs and outputs of the robot controller.

In addition to the fourth collaborative situation approved by the manufacturer and compliant with the ISO/TS 15066 standard, the application of cobots from Univeral Robots also meets the requirements of the TÜV (German,
Fig. 10. UR10 cobots company Universal Robots A/S (mechanism with six degrees of mobility, load capacity of $10 \mathrm{~kg}, 30 \mathrm{~kg}$ curb weight, range $1300 \mathrm{~mm}$ and repeatability of TCP positions $\pm 0.1 \mathrm{~mm}$ ) at a demonstration stand for box-assembly containing ordered products in shape cavities Rys. 10. Koboty UR10 firmy Universal Robots A/S (mechanizm o sześciu stopniach ruchliwości, udźwigu $10 \mathrm{~kg}$, masie własnej $30 \mathrm{~kg}$, zasięgu $1300 \mathrm{~mm}$ i powtarzalności pozycji TCP $\pm 0,1 \mathrm{~mm}$ ) na demonstracyjnym stanowisku kompletacji pudełek-skrzynek mieszczących uporządkowane produkty w zagłębieniach kształtowych [52]

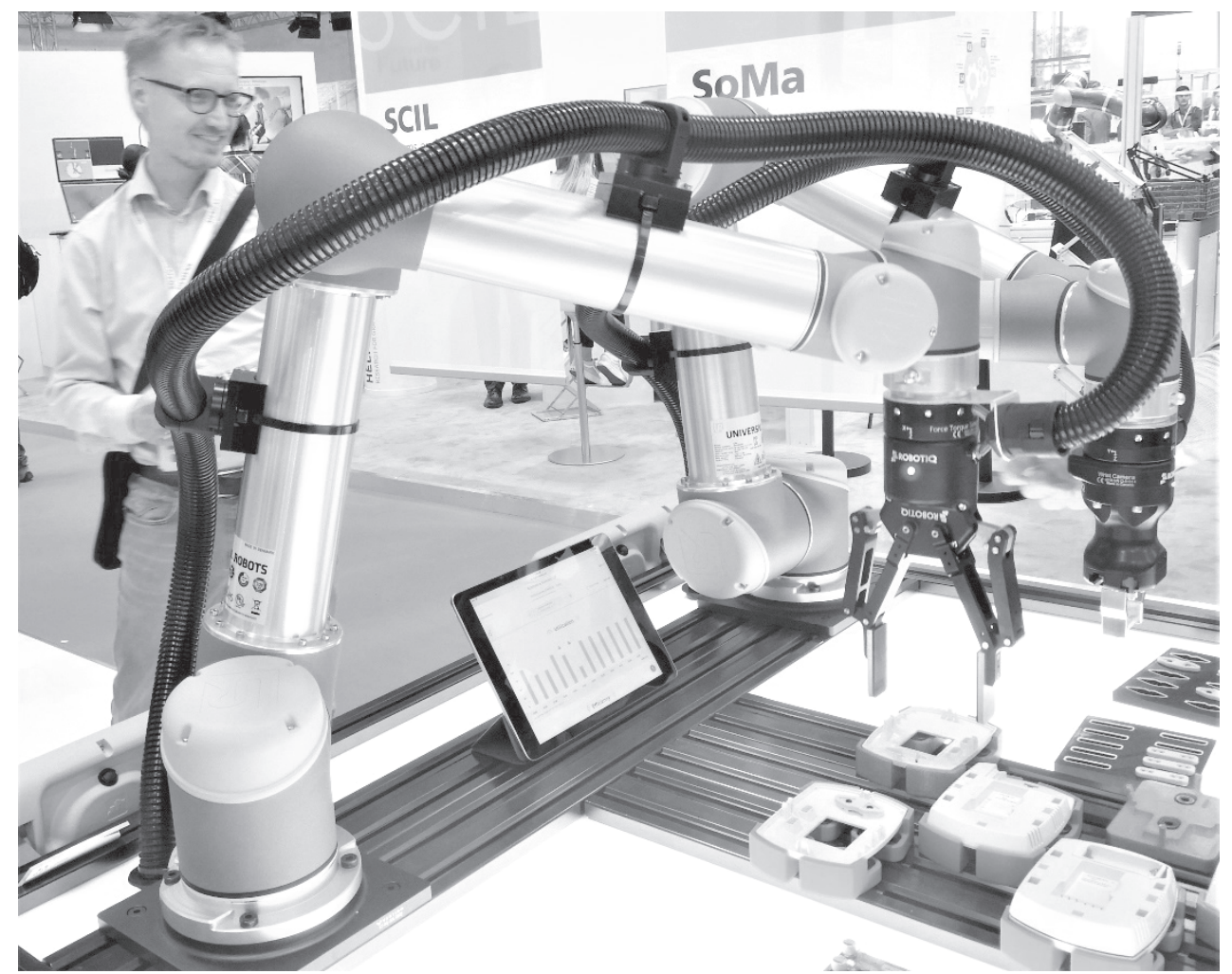


Technischer Überwachungsverein) certificate confirming the compliance of generally understood safe work of man and machine with the EN ISO 13849-1: 2008 standard, later replaced by the EN ISO 13849-1: 2016-02 standard and its Polish equivalent (Machine Safety - Elements of the Safety Related Control System - Part 1: General Design Principles) [54].

\section{Hybrid Robotics}

Already from the requirements set out in the previous point for the cobots it follows that from the point of view of the industrial robotics user there should be such a variety of robots or cobots that meets the double application requirements associated with the already mentioned problem of their presence throughout the production line. Namely, the relatively high cost of cobots, reduced movement speeds, reduced parameters of the working space and reduced load capacity, tend to make robotization applicants use non-robotized robots with conventional properties, higher movement speeds and lower prices. This is how a variety of manipulative machines called hybrid robots was created, combining (almost) conventional prices and performance with the requirements of MRK. These properties are limited, however, usually only to one selected collaborative situation according to ISO/TS 15066.

A good example of such a hybrid robot is Motoman HC10 from YASKAWA Europe $\mathrm{GmbH}$ with a motion distance of $1.2 \mathrm{~m}$ and a load capacity of $10 \mathrm{~kg}$ ( $\mathrm{HC}$ is of course Human Collaborative) [56]. This robot is designed for both standard, conventional and collaborative applications, which provides it with a slightly modified implementation of cobotic security

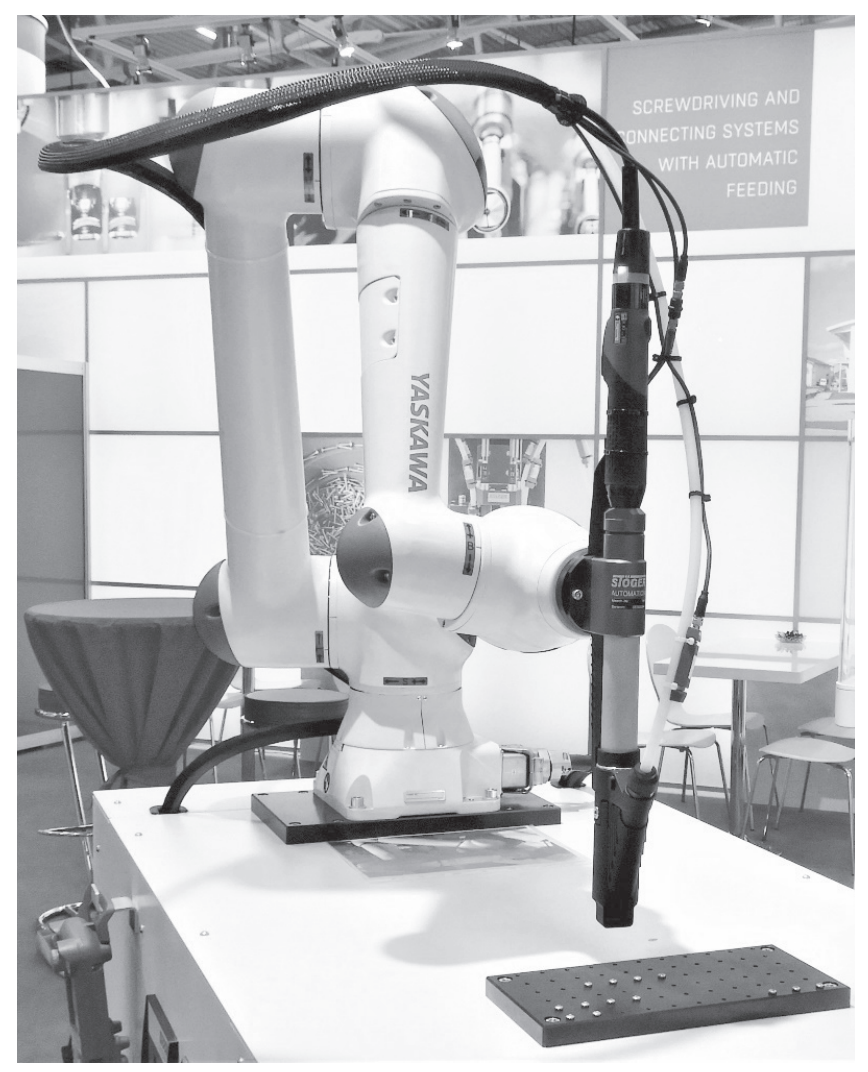

Fig. 11. Motoman HC10 hybrid robot from YASKAWA Europe GmbH with an application-adapted, specialized effector-tool, construction from Stöger Automation GmbH

Rys. 11. Robot hybrydowy Motoman HC10 firmy YASKAWA Europe GmbH z dostosowanym do aplikacji, specjalizowanym efektorem-narzędziem konstrukcji firmy Stöger Automation $\mathrm{GmbH}$ [56] according to the 4 th situation of MRK. The robot was equipped with sensory supervision of forces and moments in all six degrees of mobility of the mechanism. It is also possible to use a cobotic gripper effector or a specialized tool effector with MRK properties.

MRK hybrid modification requirements may also apply to cobots - e.g. to use, in addition to a company-equipped cobot with its specific sensory, processor and actuator accessories, in addition to a safety scanner that allows the cobot to work at speeds greater than collaborative in a situation where it's the scanned environment does not contain any unexpected object during programming. In practice, this should be understood as the division of the work space of the cobot, resulting from its kinematic structure and geometrical extent of its members, into two zones:

- an operating zone in which a cobot can behave like a conventional robot and

- to the collaboration zone where the employee may be and the cobot must meet the mentioned specific requirements of the adopted, for example 4th collaboration situation.

Therefore, when preparing a cobotic or hybrid application, the following threats should be identified, in accordance with the requirements of ISO 10218-2: 2011 (Robots and Robotic Devices - Safety Requirements for Industrial Robots - Part 2: Robot Systems and Integration) [40, 54]:

- threats related to the robotic mechanism:

- functional parameters of the mechanism: kinematic structure, geometrical mass and extensions, velocities and accelerations of motion of members and effector, generated by force drives and moments, affecting the emergence of human hazards,

- the possibility of quasi-static contact with the human body,

- mutual arrangement of workplaces: man and robot,

- threats related to the equipment of the robot mechanism:

- effectors, non-ergonomic construction solutions of grippers and tools, e.g. the possibility of dropping the transferred element, sharp edges of this element, etc.,

- the possibility of pressing the human body during the program,

- construction and location of programming and control panels, e.g. the possibility of accidentally starting or stopping the robot mechanism,

- construction and placement of other machines in the immediate vicinity of the robotic human and robot workplace,

- threats resulting from a given robot application:

- the surroundings of the human and robot workplace, e.g. temperature, noise, dustiness,

- availability of special human protective equipment,

- non-ergonomically designed trajectory of the robot effector motion.

In addition, it is appropriate to determine the risk of hazards caused by the presence of human-operator or human-employee in the operational and collaborative zone of the robot:

- the frequency and duration of human stay in the collaborative zone,

- frequency and duration of direct contact between man and robot,

- the nature of the transitions between the operational and collaboration zone,

- the nature of resetting the robot's work system: automatic or manual,

- the necessary number of employees in the collaboration zone: one or more employees and in what capacity,

- non-collaborative tasks forcing people to enter this zone. 


\section{Service Robotics}

Another large group of modern robots characterized not so much by servicing and servicing machines, stations, lines, systems and industrial processes, but above all by supporting and servicing us, people in specific life situations, from servicing the apartment and performing everyday activities, to servicing patients hospital departments, including surgical, rehabilitation and laboratory rooms, to support chronically ill, crippled or infirm people as well as medical and nursing staff who look after these people in nursing homes, retirement homes, and retirement homes, especially in hospices.

Service robots also in the mentioned industrial applications have quite specific tasks of supporting employees performing these tasks manually, without any machine support. A good example are reports from the Korean holding company Doosan Robotics Inc. on the application of service robots at car preparation stations provided by the manufacturer to the developer for further shipment or direct pickup by the customer [39]. In this case, of course, they must be hybrid service robots with clearly assigned cobotic behaviors. These service works are programmed cobotically by the employee servicing the service station and in relation to a series of several or a dozen serviced car bodies moved and set manually by the employee servicing the employee in specific places around the car body, started by performing already previously programmed tasks such as setting the customer's choice wheels and tires, recognizing the location of their mounting bolts and checking their tightening torque, checking the correct mounting of the side mirrors and their operation, installing the correct license plates, cleaning and polishing the paint, etc.

In the second, even more interesting to us, people, service area, a very interesting solution in the group of service robots is the Lio mobile cobot proposed by the Swiss company F\&P Robotics AG to serve us as a partner, as the other person, in all of the above-mentioned activities and tasks, in which we require direct contact with the other person: a doctor, a nurse, a physiotherapist, and thus serve as a personal service robot or more properly personal, serviceable [44]. Lio is a mobile machine with the P-Rob cobot mechanism moun-

Fig. 12. Service works of the Korean Doosan Robotics Inc. holding: robotized car preparation stand for pickup by the customer: wheel replacement, number setting, paint cleaning and polishing, windows, headlights, mirrors and other body parts

Rys. 12. Roboty serwisowe

koreańskiej holdingu Doosan Robotics Inc.: zrobotyzowane stanowisko przygotowania samochodu do odbioru przez klienta: wymiana kół, założenie numerów, czyszczenie i polerowanie lakieru, szyb, reflektorów, lusterek i innych elementów karoserii [19, 39]

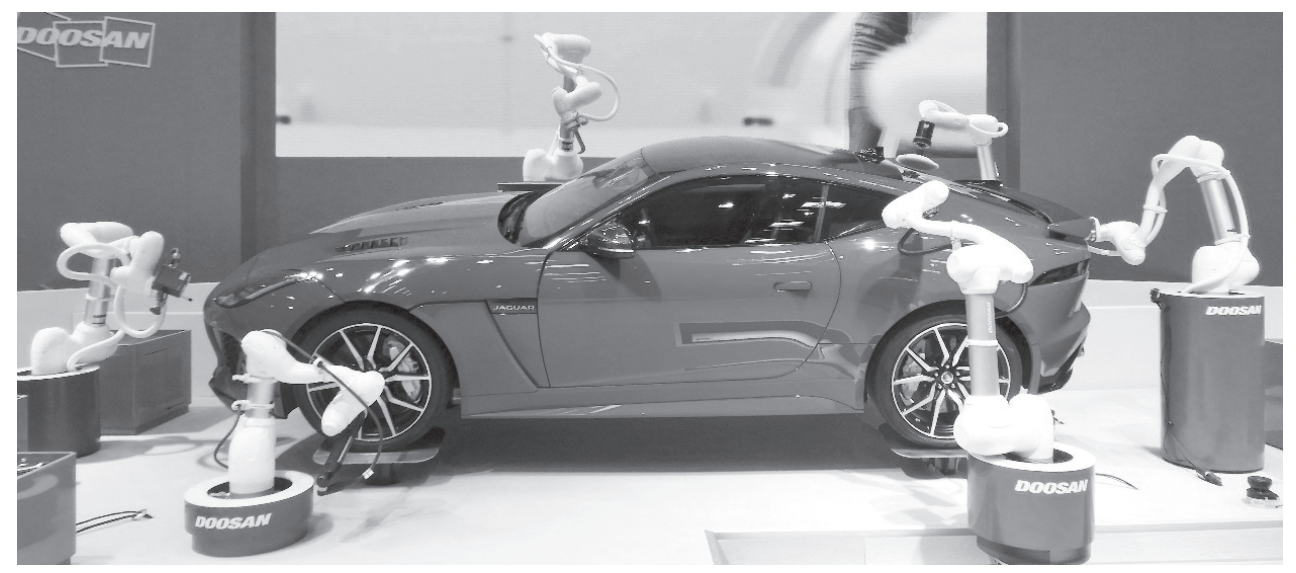

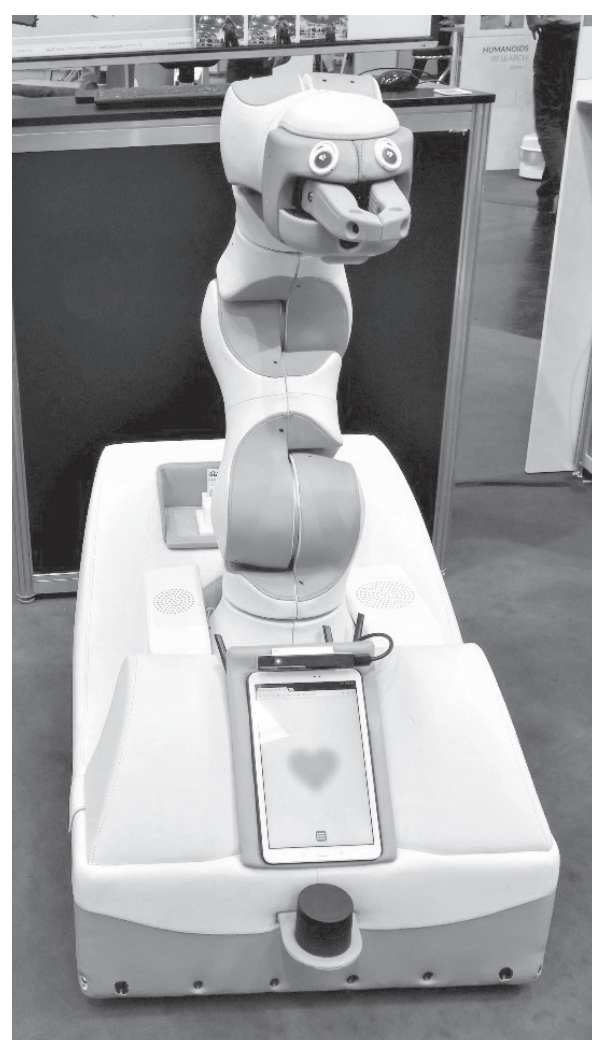

a)

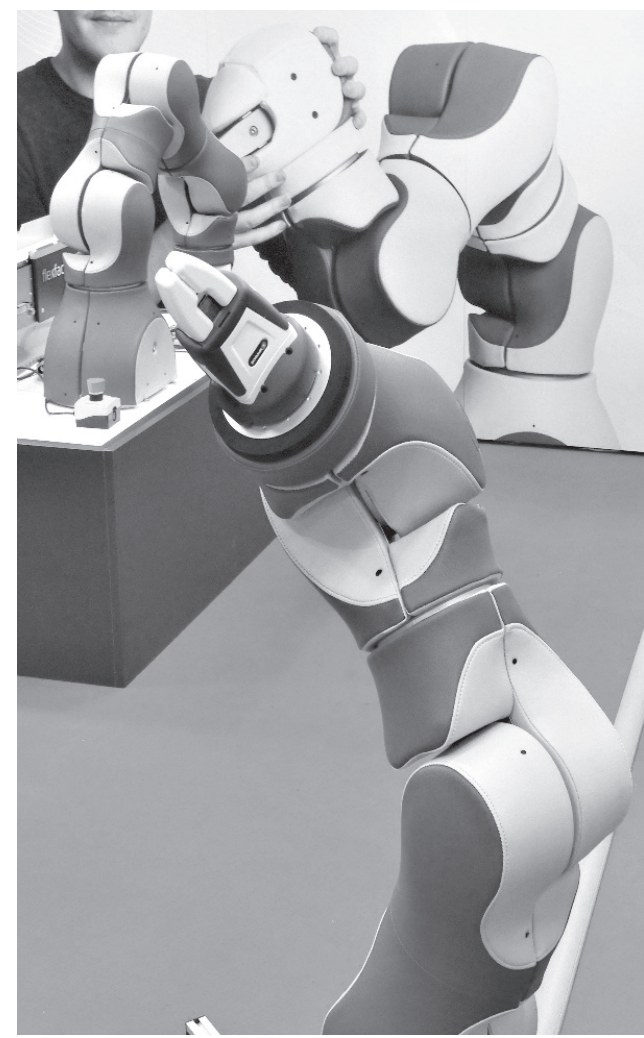

b)
Fig. 13. Service works on the cobotic properties of the Swiss company F\&P Robotics AG:

a) Lio mobile personal cobot,

b) Industrial service robots P-Rob, cobot in the foreground with the gripper of

the Schunk GmbH \& Co. KG Rys. 13. Roboty serwisowe o właściwościach kobotycznych szwajcarskiej firmy F\&P Robotics AG: a) mobilny kobot osobisty Lio,

b) przemysłowe roboty serwisowe P-Rob, kobot na pierwszym planie z chwytakiem holdingu

Schunk GmbH \& Co. KG [12, 44] 
related to new effector solutions usually use machines from other companies, attaching their own studies to them.

A great example of such a solution, well made and already having the first applications behind it, is the Yumi cobot from ABB Automation $\mathrm{GmbH}$ [35]. The machine weighs $38 \mathrm{~kg}$ and can handle an object weighing up to $500 \mathrm{~g}$ loading each of the arms. It was used in a company producing furniture hinges. It consists of two elements, which must be properly superimposed and then put together, without changing their mutual position, under two automatic screwdrivers. The assembly process ends with quality control. Here, the two-armed Yumi cobot with a video camera used in the gripper, analogously used as in the case of the already described Co-act JL1 gripper from Schunk [50], identifying the mutual position of the connected elements and checking the correctness of their connection by comparing the made hinge with the stored reference image of a well-made element. The advantage of the Yumi cobot is the possibility of using this two-arm robotization in other positions (low curb weight) and intuitive programming, through teaching, which does not require long training of the employees of the department of the applying company.

The construction of closed kinematic chains was initiated in 1947 by E.V. Gough, initially building a research stand and carrying it out professionally in 1955. It was an extremely interesting period of time when technical solutions emerged,

a)

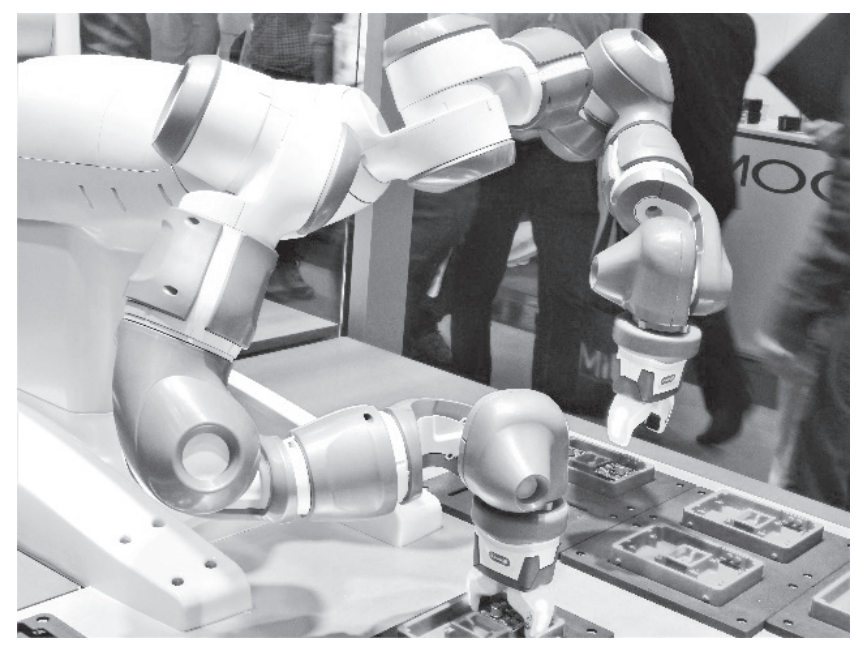

b)

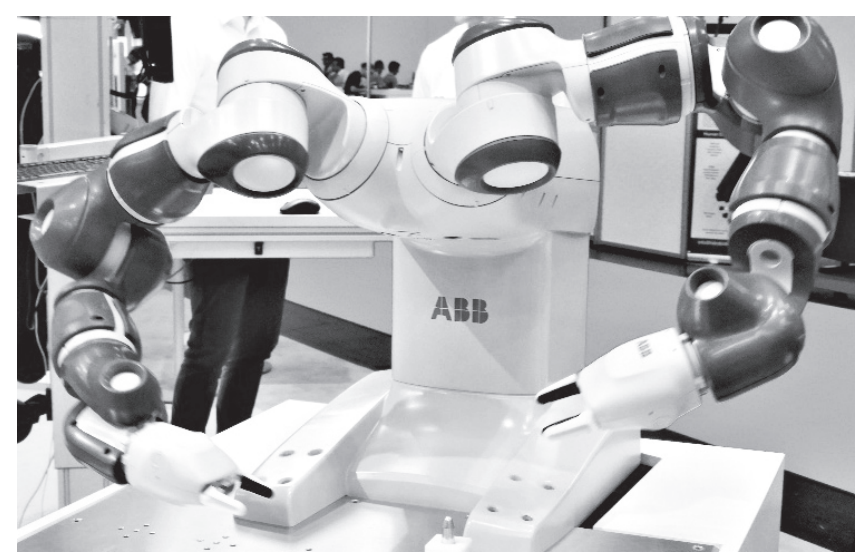

Fig. 15. Two-armed robots of the ABB Automation GmbH company with various structures and execution of platforms connecting kinematic chains of "arms":

a) with the cobotic effector of the Schunk GmbH \& Co. KG,

b) with $A B B$ effector-gripper

Rys. 15. Roboty dwuramienne firmy ABB Automation $\mathrm{GmbH}$ o różnej

strukturze i wykonaniu platform łączących łańcuchy kinematyczne „ramion”:

a) $z$ efektorem kobotycznym holdingu Schunk GmbH \& Co. KG,

b) $z$ efektorem-chwytakiem ABB [12, 35, 50]

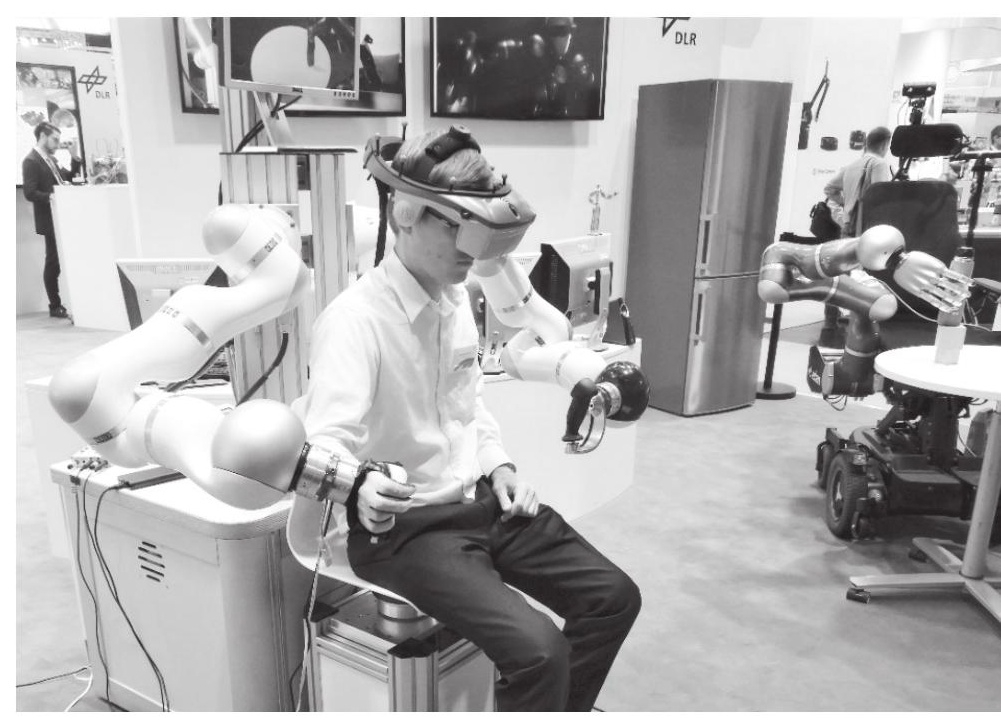

Fig. 16. The use of augmented reality and at the same time anthropomorphic, sensory glove (on the right hand) for intelligent programming of a two-armed cobot with a ten-finger gripper, Deutsches Zentrum für Luft- und Raumfahrt e.V. (DLR)

Rys. 16. Zastosowanie rozszerzonej rzeczywistości i równocześnie antropomorficznej, sensorycznej rękawicy (na prawej dłoni) do inteligentnego programowania dwuramiennego kobota z dziesięciopalcowym chwytakiem, Deutsches Zentrum für Luft- und Raumfahrt e.V. (DLR) [19, 38]

which were crucial for the future development of the machine industry. In 1948, Bill Moog builds the first electrohydraulic servo valve, thanks to which the production of numerically controlled (NC) machine tools could be started from 1954, and in the same year the first, patented, programmable industrial robot designed by G. Devol is created, and the aforementioned year appears Gough hexapod design with electrohydraulic servo drive $[11,26.27]$.

However, interest in the idea of Gough's parallel mechanism is suppressed in the 1960s by the first successes of industrial applications of serial robot mechanisms, already performed by J. Engelberger. Interest in Gough's idea sustains D. Stewart's analogous study, also hexapod, and also with hydraulic drive, described in 1966. And again it shifts to the margin of robotics by introducing electric drive and processor control in industrial robots in 1974 by the Swedish group ASEA [18, 20]. It wasn't until the late 1980s and the 1990s that the twentieth century was ending that there was interest in parallel mechanisms. This time in a dipod or more often tripod design, with three kinematic chains articulated (class III connections) with a connector, called Stewart's platform in robotics slang. An effector was mounted in series to this platform and two or more kinematic members were mounted on it, increasing the total mobility to four or five degrees of mobility.

Initially, pneumatic, piston rod and rodless cylinders servo-controlled were used as drives, since the first decade of the $21^{\text {st }}$ century electric servo drives have been gradually becoming more common. At this point it is worth mentioning and this applies to all of the described robotics, about technological changes, also affecting the area of machine and robot propulsion and causing in the last several years evolutionary, but now a very clear departure from propulsion solutions related to pneumatics [13].

The 50 s, 60 s and 70 s of the last century, when pneumatics became the basic, practically the only means of automating production processes, were the period of uniquely intensive development of control and drive pneumatics. However, as early as the 1980s and 1990s, pneumatic information acquisition and processing devices, both continuous and discrete, were replaced by electronic and processor devices. Pneumatic applications have remained and remain the actuator drives of 


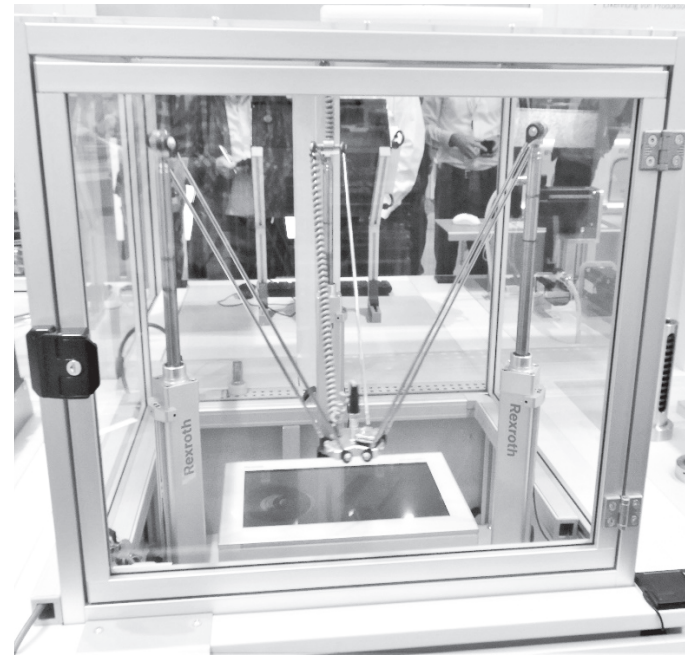

a)

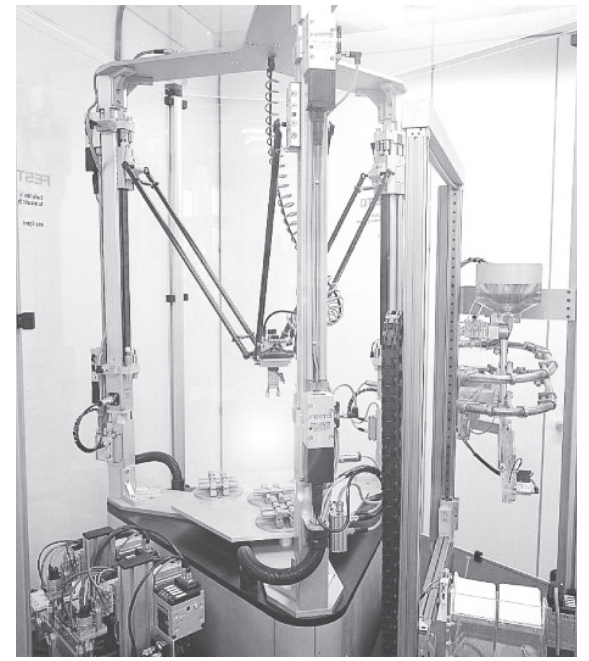

b)
Fig. 17. Multi-chain closed kinematic works with electropneumatic actuator drive: a) with a double-chain mechanism (dipod), piston rod drive, Bosch Rexroth AG,

b) with a three-chain mechanism (tripod), rodless drive, Festo Vertrieb GmbH und Co. KG Rys. 17. Roboty wielołańcuchowe o zamkniętej strukturze kinematycznej z elektropneumatycznym napędem siłownikowym:

a) z mechanizmem dwułańcuchowym (dipod), napęd tłoczyskowy, Bosch Rexroth AG, b) z mechanizmem trójłańcuchowym (tripod), napęd beztłoczyskowy, Festo Vertrieb $\mathrm{GmbH}$ und Co. KG $[37,43]$ automated and robotic production processes, but the relative area of their applications is clearly accelerating reduction in favor of electric drive, even after the design of throttled controlled pneumatic actuators has been transformed into servopneumatic and pneumotronic actuators [13-15].

Three factors influenced the development of new, competitive to drive pneumatics, solutions and applications of electric drives and servo drives in industrial robotics:

- the aforementioned introduction in the 1990s of new magnetic materials, primarily neodymium, increasing the energy efficiency of electric motors with their significantly reduced mass and volume,

- indisputably easier direct supply of electricity to the actuators of machines and robots than it is the case with the supply of pressure energy and compressed flow of air, by means of this electricity,

- the need to save energy, both due to the rising costs of obtaining and using it, as well as the rapidly spreading awareness of the negative environmental impact of obtaining energy from conventional sources and materials. In the case of pneumatics, it is particularly unfavorable to generate energy supplying the actuator controls twice, drastically deteriorating the energy efficiency of these devices.

Examples showing definitely better effects and technical and energetic solutions of electrical compared to pneumatic ones have been given for several years now, initially with some dis- belief, now with full conviction that the choice of electrical solutions is right. The investment cost of the electric actuator with all necessary components, in this example, was still in 2018 about $260 \%$ of the investment cost of the pneumatic actuator, including all necessary components for its use. However, this cost was depreciated after 5 months of using the actuator. However, at the moment (2019), the actuator manufacturers ensure that the investment costs of both solutions are equal! [19].

The fact of carbon dioxide emissions is also not without significance. In the case of approx. 24,000 kWh of energy needed additionally to maintain the operation of the exemplary pneumatic cylinder in relation to the electric cylinder, it is also an additional emission of approx. 12,000 $\mathrm{kg}$ of $\mathrm{CO}_{2}$ after adoption, e.g. for Germany, the equivalent of carbon dioxide emissions at the level of approx. $500 \mathrm{~g} \mathrm{CO}_{2} / \mathrm{kWh}$ called the "carbon footprint" [19].

Returning to multi-chain robots - the advantages of the most commonly developed electric drive tripods include:

- a much more "rigid" mechanism construction compared to series mechanisms, which undoubtedly has a beneficial effect on improving the quality of the effector positioning (repeatability of the effector position in the range of hundredths of a millimeter), which in turn predisposes multi-chain robots for the production of devices built on a micro scale and nanotechnology,

- to the disadvantages:

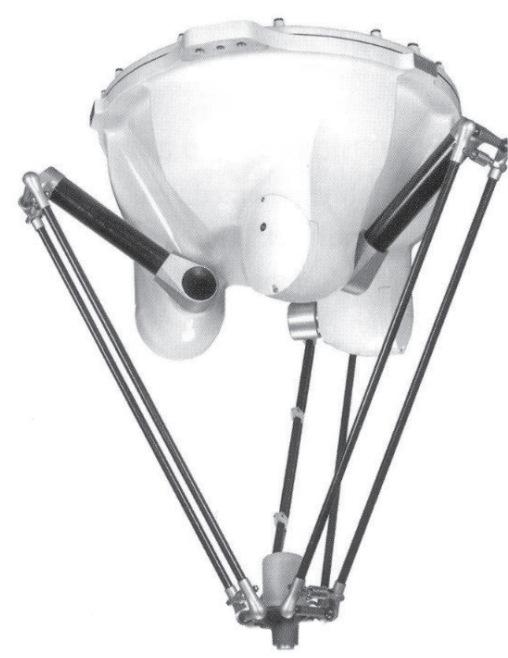

a)

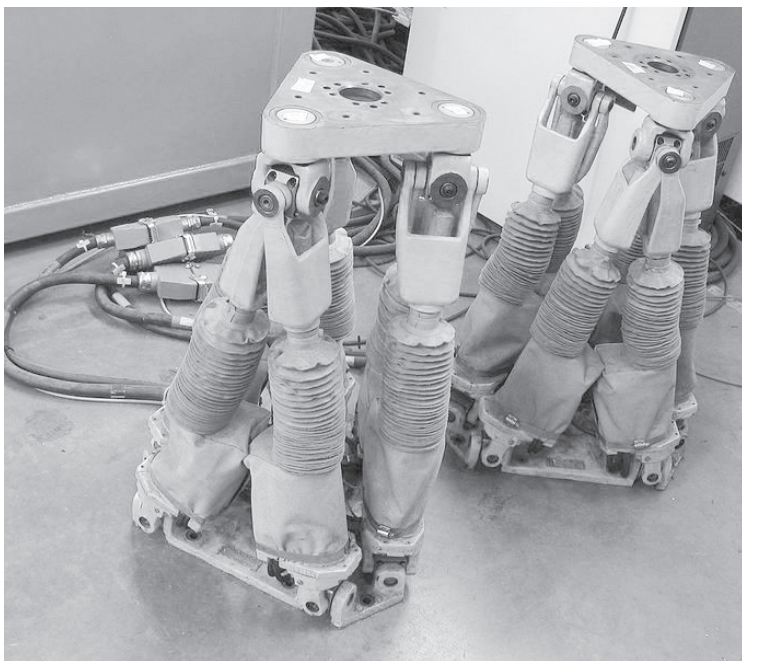

b)
Fig. 18. Multi-chain robots with a closed kinematic structure and various drives:

a) with a three-chain mechanism (tripod), with an electric motor drive, with four levels of mobility, b) with a six-chain mechanism (hexapod), with six levels of mobility, with an electrohydraulic actuator, a Japanese company AKA Rys. 18. Roboty wielołańcuchowe o zamkniętej strukturze kinematycznej i różnych napędach: a) z mechanizmem trójłańcuchowym (tripod), z elektrycznym napędem silnikowym, o czterech stopniach ruchliwości,

b) z mechanizmem sześciołańcuchowym (heksapod), o sześciu stopniach ruchliwości, z elektrohydraulicznym napędem siłownikowym, japońska firmy AKA [19] 
Fig. 19. Robotino, a mobile robot from Festo AG \& KG for research and training in Industry 4.0: a) a traveling platform with a column and one of three platforms supporting production modules by its own effectors, b) mechanism with 3 levels of local mobility of the robot effector Rys. 19. Robotino, robot mobilny firmy Festo $A G$ \& KG dla prac badawczych i szkoleniowych w obszarze Przemysłu 4.0: a) platforma jezdna wraz

z kolumną i jedną z trzech platform obsługujących moduły produkcyjne przez własne efektory,

b) mechanizm o trzech stopniach ruchliwości lokalnej efektora robota $[19,43]$

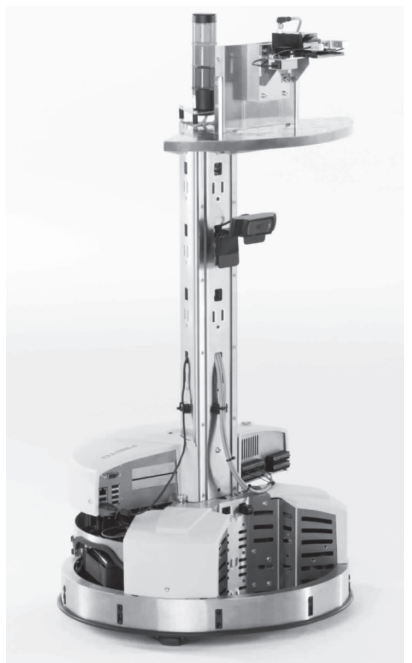

a)

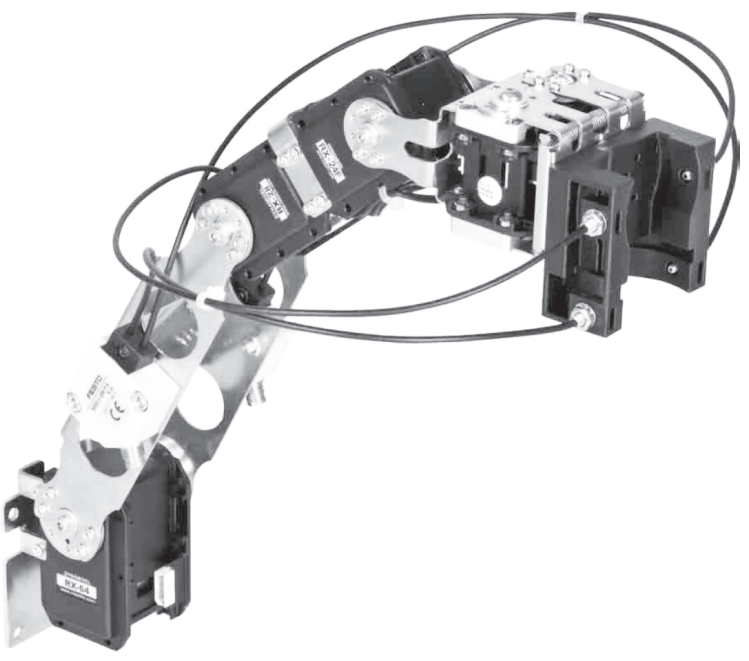

b)
- definitely smaller workspace, which in production applications carried out on a micro and nanotechnology scale is not of great importance,

- higher cost and price of these machines compared to conventional design robots,

- collaborative versions are more difficult than in the case of cobots with serial mechanisms - hence, at least in the solutions encountered, multi-chain mechanisms are protected in closed application processes.

\section{Mobile Robotics}

The first machines belonging to the subclass of industrial, autonomous mobile robots (mobile robots, Automated Guided Vehicles - AGVs or Autonomous Intelligent Vehicles - AIVs) appeared at the beginning of the last decade. Taking into account only machines with a currently noticeable practical significance, they can be divided into two clearly different groups of solutions:

- mobile robots supporting modules and production departments of Industry 4.0. These machines are still used in the research, development and implementation phases of the manufacturing process transformations, ultimately in line with the assumptions of Industrial Transformation 4.0 [17, 25],

- autonomous mobile robots designed for intralogistic-house transport of products, materials and tools, i.e. automation and robotization of the production area, also intralogistics, logistics, palletizing and storage $[4,5]$.

An example of a mobile robot solution of the first group of machines intended for the areas of Industry 4.0 is Robotino, a locomotion and handling machine, available in two versions: Basic Edition and Premium Edition. They differ in the intensity of computer processing, the volume of internal memory and the details of the platform and column, e.g. in the Premium version, you can use three column platforms that support different production modules [19, 43].

Robotino is equipped with three servo electrically driven modules, providing the possibility of moving the platform in three directions of motion and omnidirectional regional rotation at the stop, and identically driven three elements of local motion embedded on them effector - thus a total of seven degrees of mobility of the final effector. The position of the mechanism is controlled by nine infrared sensors, with the additional option of retrofitting the machine with two optical and one inductive motion tracking sensor. The power supply is provided by $12 \mathrm{~V}$ batteries with a controlled level of charge and a power station.

Computer control with COM Express specification, using an Intel Core i5, 2.4 GHz or Intel Atom, 1.8 GHz processor. The operation of the operating and utility systems is protected by a 32 GB SSD drive or 64 GB optional. The work of four DC motors of the mobile platform movement is directly controlled by a 32 bit processor, generating PWM signals using the FPGA interface and receiving signals from encoders coupled with four motors driving the mobile platform.

The movement of the robot column and its local parts are programmed by computer-assisted learning, implemented as graphic programming, based on a computer simulation image of the production department with a robot embedded in it. Teaching itself can be implemented by one of the previously selected methods used in modern conventional robotics. Computer - machine communication is provided via wireless LAN. For system startup and simulation, the interface (API) supports the use of various systems and languages, including Windows XP, Vista, Windows $7 / 8 / 10, \mathrm{C} / \mathrm{C}++$, JAVA Net, LabVIEW and MATLAB/Simulink, Robot Operating System (ROS SmartSoft) and Microsoft Robotics Developer Studio.

Robotino performance parameters [43]:

- traffic maps in the area of $20-5600 \mathrm{~mm}$, traffic speed up to $10 \mathrm{~km} / \mathrm{h}$

- load capacity $30 \mathrm{~kg}$, curb weight $20 \mathrm{~kg}$,

- platform diameter $450 \mathrm{~mm}$,

- tactile contact zone of the platform sensory supported,

- HD 1080 px video camera with USB interface.

Moving to internal transport machines, their first solutions appeared almost parallel to the first industrial robots, i.e. in the $1950 \mathrm{~s}-60 \mathrm{~s}$. of the $20^{\text {th }}$ century. These machines have gone, along with the development of industrial robotics, a long way to introduce new, innovative solutions, associated primarily with the implementation of autonomous traffic and in the area of maximum speeds of several meters per second and safe behavior for workers encountered on the roads of this movement. The presence of these employees in typical applications of internal transport machines cannot be simply excluded in industrial practice.

A good, proven example of such a solution is the VersaBot $500 / 700$ mobile robot, a young company created in 2013, the Polish company VersaBox $[5,55]$. The robot can navigate the colored line, use the laser mapping system of the traffic environment, implementing in it autonomous, intelligent, safe behaviors, checking in the company of other dozen mobile robots and special versions, designed for so-called clean production 


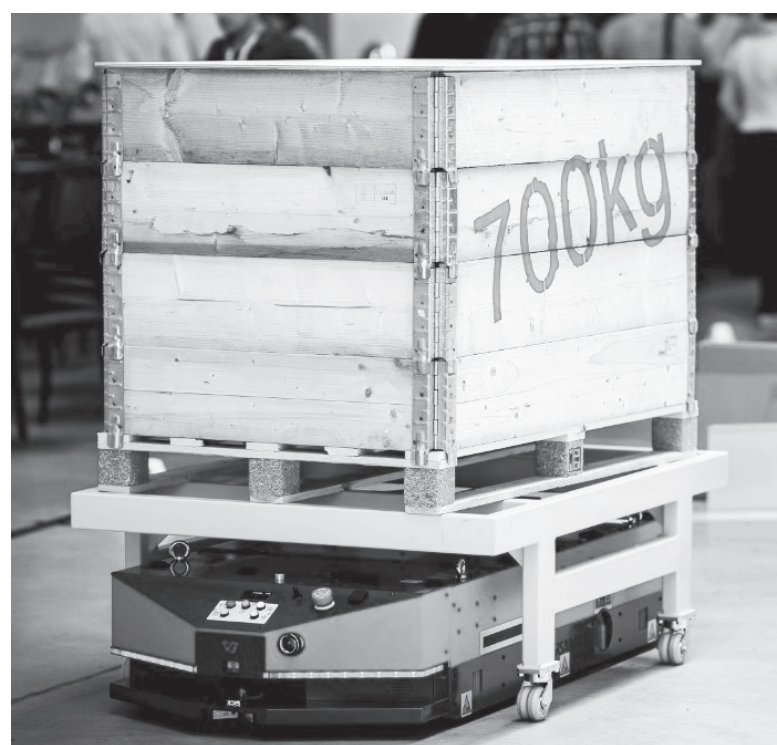

a)

Fig. 20. Autonomous mobile robots (AGV) for intralogistic transport: a) VersaBot 500/700 by VersaBox Sp. z o.o., b) LD from Omron

Rys. 20. Autonomiczne roboty mobilne (AGV) transportu wewnętrznego: a) VersaBot 500/700 firmy VersaBox Sp. z o.o., b) LD firmy Omron [47, 55] rooms, including in the food industry. It can work as a towing vehicle, is equipped with a pallet jack, ensures assembly of roller feeders and adapters for the mounting of manipulative mechanisms. The company cooperates with system integrators, also supports leasing solutions.

In recent years, interesting solutions have emerged for automated and robotic mobile stations carrying out selected tasks related to further technical rationalization of logistics and intralogistics, especially palletization. This applies not only to manufacturing companies, but above all to logistics companies that provide co-packing services, i.e. packaging and repackaging of products or their sets within contract logistics. It encourages the development and application of these solutions of modern universality, including the Internet of these processes and their special time-consuming nature, especially in confrontation with the lack of employees.

An interesting implementation of this concept is the diploma, master's project, carried out by Piotr Kwiatkowski in 2019 [8], conducted at the Institute of Automatic Control and Robotics of the Warsaw University of Technology, in cooperation with the international company Kuehne + Nagel [48], offering dedicated solutions in the field of international and domestic air and sea forwarding, road, rail, as well as contract and integrated logistics as well as integrator of station execution, Biuro Inżynierskie Sp. z o.o. The project was implemented within 4 months, the cost - about 250 thousand PLN. The work was honored in the 'Young Innovative' Competition, PIAP, in 2019 and the Siemens and Rector Award of the Warsaw University of Technology in 2019.

Important for the successful implementation of the project was the use of a Universal Robots A/S [52] cobot station in the construction of a robotic program for palletizing products and for coordinating the station's overriding work - the Siemens Simatic S-7 1200 controller [51]. The most important station parameters [8]:

- number of pallet places -2 ,

- supported pallets: $800 \mathrm{~mm} \times 1200 \mathrm{~mm}-$ EUR1,

- maximum palletizing height $-2000 \mathrm{~mm}$,

- maximum number of cycles per minute - 8,

- number of scanners for safe cobot operation -3 .

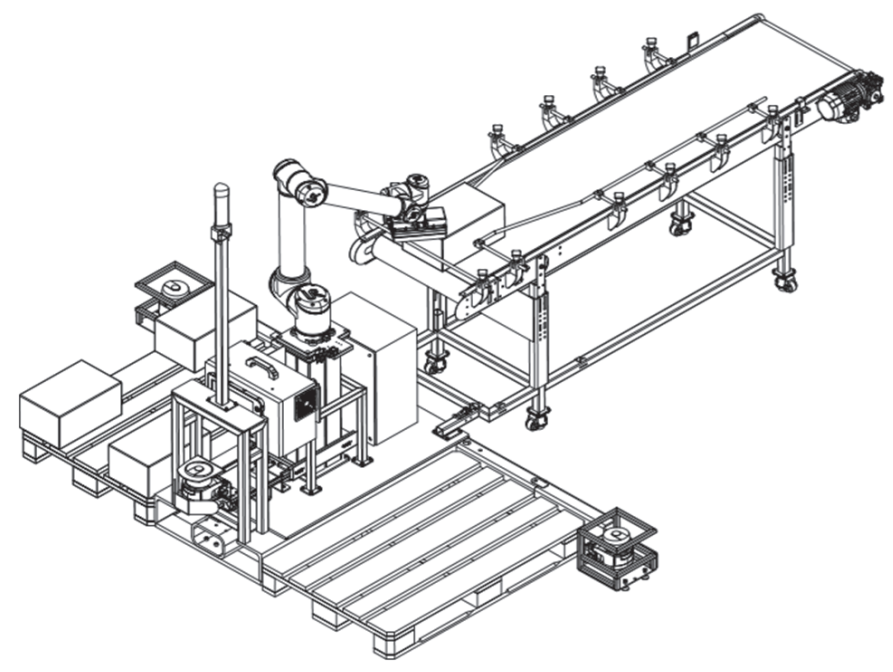

a)

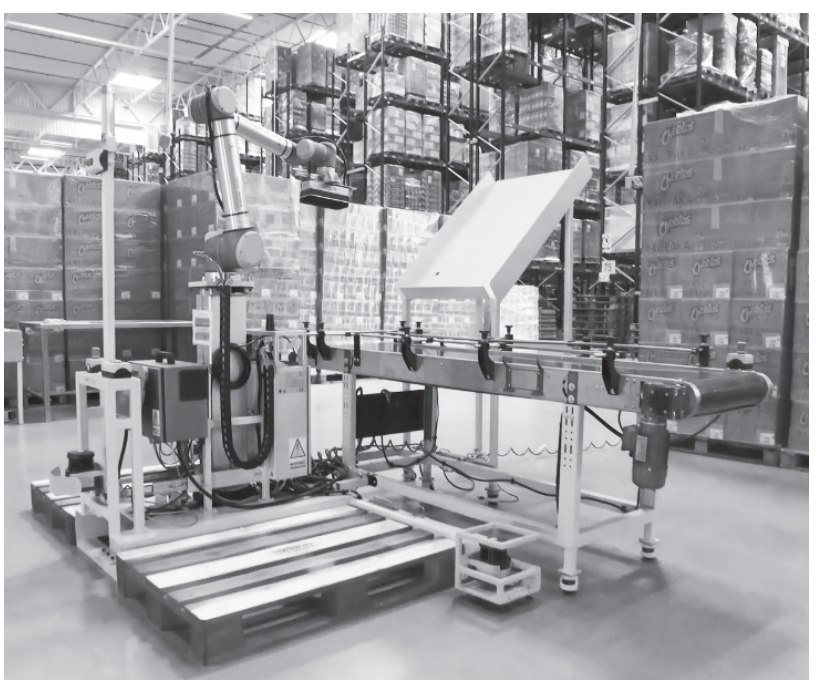

b)

Fig. 21. A robotized, mobile palletizing station with a cooperating robot: a) sketch of the project solution, b) made palletizing station

Rys. 21. Zrobotyzowana, mobilna stacja paletyzująca z robotem współpracującym: a) szkic rozwiązania projektu, b) wykonana stacja paletyzująca [8, 48] 


\section{Conclusions}

And ending the essay on modern intelligent robotics: the tasks of cobotics, hybrid, service, autonomous mobile and multi-chain robotics, require extremely wide, multidisciplinary, well-established knowledge and practical experience in the field of work ergonomics, basics of mechatronics, sensorics, processors and actuatorics, including in particular the basics of the construction and properties of the listed robotic solutions, in their modern generation and shape - should not be surprising to the statements of practitioners - professionals (ASTOR, May 2019 [33]) that:

- I do not think, in order to soon cobots can replace the classic robots... - Zbigniew Proch (Company RENEX), and also - In Polish industry, the introduction of traditional robots is much more profitable than cobots... - Stefan Życzkowski (Chairman of the Board of Directors of ASTOR).

In order to change this state of affairs in Poland, it is necessary here to formulate new content and forms of vocational education and new specializations, with a simultaneous emphasis on increasing the importance and number of mechatronics engineers and mechatronics engineering professions: production, automation, robotics, actuatorics, sensorics, computer science, industrial informatics industrial engineer, also industry 4.0 engineer and cyberinformatics, also engineers for Industry $4.0[6,25,28]$. This change is required by the need to shape and support the career paths of technical and engineering staff whose knowledge and experience will be absolutely crucial in Industry 4.0 for the market success of a given enterprise. Post-graduate studies are also indispensable here, in June 2019 the Rector of Warsaw University of Technology has just established new Post-graduate Studies in Industrial Transformation 4.0 at the Faculty of Mechatronics of Warsaw University of Technology - it is planned to launch them already in this academic year $(2019 / 2020)$ or in next year in October 2020/2021 [19].

\section{References}

1. Bord of Management, Messe München GmbH: automatica, Optimize your Production. Face the Future of Manufacturing. Final Edition (2018), [www.automatica-munich.com].

2. Bock Th., Construction Robotics Enabling Innovative Disruption and Social Supportability. [in:] Proceedings of the International Symposium on Automation and Robotics in Construction (ISARC), 2015. Vilnius Gediminas Technical University, Department of Construction Economics \& Property, Vilnius, 1-11.

3. Brüninghaus J., Stum S., Nelles J., Mertens A., Schlick Ch., Brell-Cockan S., Arbeitsorganisatorische und ergonomische Anforderungen an die Mensch-Roboter-Interaktion auf der Baustelle der Zukunft. Kongress der Gesellschaft für Arbeitswissenschaft e.v., RWTH Aachen, 2016.

4. Chołodowicz E., Figurowski D., Mobile Robot Path Planning with Obstacle Avoidance Using Particle Swarm Optimization, "Pomiary Automatyka Robotyka", Vol. 21, No. 3, 2017, 59-67, DOI: 10.14313/PAR_225/59.

5. Chojecki R., Olszewski M., A Mobile Robot for Laboratory Purposes and its Applications. "Pomiary Automatyka Kontrola", Vol. 55, No. 3, 2009, 190-193.

6. Kaliczyńska M., Kluczowe technologie Przemystu 4.0 (Key Technologies of Industry 4.0). „Automatyka”, Vol. 4, No. 1-2, 2018, 95-96.

7. Kohler M., Gramazio F., Willmann J., The Robotic Touch: How Robots Change Architecture, ETH Zurich, Zurich Park Books, 2014.

8. Kwiatkowski P.K., Zrobotyzowana mobilna stacja paletyzujaca z robotem wspótpracujacym (Robotized, mobile palletiza- tion station based on collaborative robot). Praca dyplomowa magisterska (promoter M. Olszewski, work awarded in the Competition "Young Innovations", PIAP, in 2019 and by Siemens and the Rector of Warsaw University of Technology, in 2019), Warsaw University of Technology (2019).

9. Łaski P.A., Kinematic Analysis of Parallel Manipulators. Publisher Politechnika Świętokrzyska, M121, Kielce 2019.

10. Łaski P.A., Takosoglu J.E., Błasiak S., Design of a 3-DOF tripod Electro-pneumatic Parallel Manipulator. "Robotics and Autonomous Systems", Vol. 72, 2015, 56-70, DOI: 10.1016/j.robot.2015.04.009.

11. Merlet J.-P., Solving the Forward Kinematics of a Goughtype Parallel Manipulator with Interval Analysis. "International Journal of Robotics Research", Vol. 23, No. 3, 2004, 221-235, DOI: 10.1177/0278364904039806.

12. Olszewski M., automatica 2018. Optimize your Production. "Automatyka", Vol. 4, No. 10, 2018, 107-122.

13. Olszewski M., Basics of Servopneumatics. VDI Verlag, Düsseldorf 2007.

14. Olszewski M., Bionika (Bionics). "Automatyka", Vol. 4, No. 6, 2018, 111-116.

15. Olszewski M., Mechatronika (Mechatronics). „Automatyka”, Vol. 4, No. 1-2, 2018, 97-99.

16. Olszewski M., Mechatronizacja produktu i produkcji - Przemyst 4.0 (Mechatronization of the Product and the Production - Industry 4.0), „Pomiary Automatyka Robotyka”, Vol. 20, No. 3/2016, 13-28, DOI: 10.14313/PAR_221/13.

17. Olszewski M., Przemyst 4.0 (Industry 4.0). "Automatyka”, Vol. 4, No. 1-2, 2018, 99-104.

18. Olszewski M., Rozwój robotyki (Development of Robotics), Part I, Essay Robotics. „Automatyka”, Vol. 5, No. 3, 2019, 159-168.

19. Olszewski M., Wspótczesna robotyka (Modern Robotics), Part III, Essay Robotics. „Automatyka”, Vol. 5, No. 9, 2019, 89-107.

20. Olszewski M., Robotyka w Polsce (Robotics in Poland), Part II, Essay Robotics. „Automatyka”, Vol. 5, No. 3, 2019, 169-182.

21. Olszewski M., Wojtowicz J., Wrona S., Dąbrowska-Żółtak K., Mechatronika w architekturze - architektronika (Architecture with Mechatronics - Architectronics). „Pomiary Automatyka Robotyka", Vol. 21, No. 3/2017, 11-25, DOI: $10.14313 / \mathrm{PAR} \_225 / 11$.

22. Panasiuk J., Kaczmarek W.: Robotyzacja procesów produkcyjnych (Robotization of Production Processes). PWN, Warszawa 2017.

23. Piątek Z., Collaborative and Mobile Robots. AGV Report from the Market. APA - Automatyka Podzespoły Aplikacje, Reports 2019.

24. Pilz T., Neue Wege in der Robotik beschreiten. Robotik und Produktion. Integration, Anwendung, Losungen, No. 3, 2018, 8-10.

25. Poreda R., Gracel J., The Introduction of Robotics. Six Common Mistakes. Automatyka, 3(3), pp. 40-42 (2019)

26. Robotik und Production, Integration, Anwendung, Lösungen. (in) Highlights der automatica, Vol. 3, No. 3, TeDo Verlag GmbH, Marburg 2018.

27. Industry Robotics. The Domestic Market in 2018. APA Automatyka Podzespoły Aplikacje, Reports 2018.

28. Staniszewska A., Zrobotyzowany przemyst (The Robotised Industry). Automatyka, Vol. 5, No. 3, 2019, 30-36.

29. Stoll W., Bionik. Lernen von der Natur - Impulse für Innovation. Edition Festo, Esslingen 2018.

30. Stoll W., Bionics. Inspiring Technology. Verlag Hermann Schmidt, Mainz 2012.

31. Stumm S., Braumann J., von Hilchen M., Brell-Cokcan S., On-site Robotic Construction Assistance for Assembly Using a-priori Knowledge and Human-Robot Collaboration. 
[in:] Rodić A., Boranglu T. (eds), Advances in robot design and intelligent control, Vol. 540, Springer 2017.

32. Zhang D., Parallel Robotic Machine Tools. Springer, New York, Heidelberg 2010.

33. www.astor.com.pl - ASTOR Publications,

34. www.automatica-munich.com - Bord of Management, Messe München $\mathrm{GmbH}$,

35. www.abb.de/robotics - ABB Automation GmbH,

36. www.beckhoff.de - Beckhoff Automation GmbH \& Co. KG,

37. www.boschrexroth.de - Bosch Rexroth AG,

38. www.dlr.de/m - Deutsches Zentrum für Luft- und Raumfahrt e.V. (DLR), Institut für Robotik und Mechatronik,

39. www.doosanrobotics.com - Doosan Robotics Inc,

40. www.eu-nited.net/robotics - EUnited Robotics - The European Robotics Association,

41. www.epson.eu - Epson Europe B.V.,
42. www.fanuc.eu - Fanuc Deutschland GmbH,

43. www.festo.de - Festo Vertrieb GmbH und Co. KG,

44. www.fp-robotics.com - F\&P Robotics AG,

45. www.gudel.com - Güdel Group AG,

46. www.ifr.org - International Federation of Robotics,

47. industrial.omron.pl - Omron Electronics Sp. z o.o.,

48. www.kuehne-nagel.pl - Kuehne+Nagel Sp. z o.o.

49. www.kuka.com - KUKA AG,

50. www.schunk.com - Schunk GmbH \& Co. KG,

51. www.siemens.com - Siemens AG,

52. www.universal-robots.com - Universal Robots A/S,

53. www.cit-ec.de - Universität Bielefeld, Cluster of Excellence Cognitive Interaction Technology (CITEC),

54. www.vdma.org/r+a - VDMA Robotik + Automation, 55. pl-pl.facebook.com/versabox.pl - VersaboX Sp. z o.o., 56. www.yaskawa.eu.com - YASKAWA Europe GmbH.

Streszczenie: Roboty stały się w mijającym dziesięcioleciu podstawowymi narzędziami automatyzacji i robotyzacji produkcji przemysłowej, tak jak kiedyś, w latach 70. sterowniki programowalne, w latach 80. procesorowe regulatory napędów, w latach 90. XX wieku nastawniki częstotliwościowe silników prądu przemiennego i w pierwszych latach XXI wieku cyfryzacja, wyrażająca się istotnym zaawansowaniem i upowszechnieniem informatyzacji, telekomunikacji i internetyzacji. Świadectwem tej roli jest dalsze, poza obszary konwencjonalnej robotyki, rozszerzanie jej aplikacji i pojawienie się nowych rozwiązań sprzętowych i programowych ukierunkowanych na wspólne, przez roboty i człowieka, podejmowanie dotychczas nie racjonalizowanych zadań produkcyjnych. Tym właśnie przemianom we współczesnej robotyce poświęcony jest ten esej.

\section{Prof. Mariusz Olszewski, PhD, DSc}

marindustry4.0@gmail.com ORCID: 0000-0003-3516-2942

An employee of the Warsaw University of Technology since 1965, a scholarship holder of the Alexander v. Humboldt Foundation in the 1970s, internships and work in German universities and companies in the 1980s. In 1978 he organizes the first scientific conference on industrial robotics in Poland, in 1985 WNT publishes the first Polish monograph on industrial handling machines written under his supervision, in the past decade the REA publishing house has published

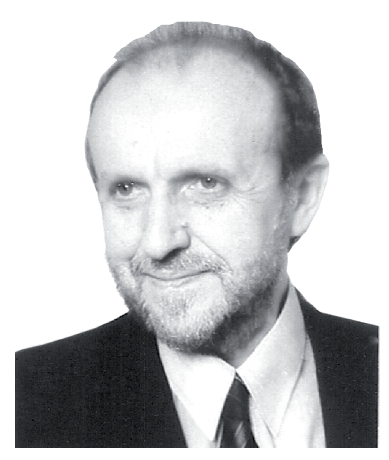

the first Polish mechatronics textbooks written under his supervision: "Mechatronics" (2002), "Fundamentals of Mechatronics" (2006) and two-volume "Mechatronic Devices and Systems" (2009). A specialist in the field of drive and control of machines and industrial robots. Director of the Institute of Automatic Control and Robotics at the Mechatronics Faculty of the Warsaw University of Technology in 1994-2012; member of the Scientific Council of the Industrial Institute of Automation and Measurements (PIAP) in the years 2003-2017; vice-chairman of the Technical-Education-Committee at the Polish-German AHK in Warsaw since 2010. The founder of the scientific and technical consulting company marlndustry 4.0 in the area of mechatronization, automation, robotization, computerization and internetization of industrial production - Industry 4.0, from 2016. 